\title{
A FRAGMENTAÇÃO NA ATUAL POESIA BRASILEIRA
}

Nea de Castro (FURG)

RESUMO: A fragmentação é estratégica prioritária na lírica hesitante da atualidade. $\mathrm{Na}$ cena brasileira, o código poético, que se afirma em poetas como Cláudia RoquettePinto, Rodrigo Garcia Lopes, Arnaldo Antunes e outros, procura recolher as dispersões, lacunas, interstícios, interconexões, que vêm caracterizando a Era das Reciclagens, mesmo num país periférico como Brasil. No horizonte crítico, ainda relativamente impreciso, a poética da hesitação elabora perfis e ritmos para a ausência de fixidez do sentido, em meio às tensões entre globalização e localismos. PALAVRAS-CHAVE: Fragmentação - Poesia - Literatura Brasileira Contemporânea

Uma imagem da contemporaneidade é sugerida - ou apenas pressentida - por JeanFrançois Lyotard nesta reflexão sobre o pensamento do filósofo e sinólogo François Jullien: um "longo percurso oblíquo entre terrenos incertos" (1998: 11). Nesse contexto, um grupo de autores vêm constituindo uma poética da hesitação, que tem como estratégia prioritária trazer para o primeiro plano a fragmentação do dizer e dos sentidos. As conclusões parciais apresentadas aqui se relacionam ao projeto "A lírica pós-moderna no Brasil": estudos de Paulo Henriques Britto, Age de Carvalho, Augusto Massi, Alexei Bueno, Arnaldo Antunes, Rodrigo Garcia Lopes, Alckmar Luiz dos Santos, Adriano Espínola, Cláudia Roquette-Pinto e Valdo Motta. ${ }^{1}$

Fragmentos do corpo, do desejo, decompõem a cena primitiva, bíblica, da sexualidade e, simultaneamente, atualizam-na, em No Éden, de Cláudia Roquette-Pinto. Pela estratégia da fragmentação, deslizam para a cena a memória da infância, outras identidades, e o peso das coisas. Ao mesmo tempo, o leitor acompanha a desmontagem da única estrofe, dos versos e das palavras - com efeitos na acumulação de sentidos e na indeterminação da voz poética - através dos recursos da proliferação de vozes (na segunda e na terceira pessoas, e no impessoal), do espaço em branco e do uso de apenas duas pontuações, a vírgula e os parênteses (estes, utilizados intensamente). Tais recursos e mais a estratégia do minimalismo, que recorta e distribui os versos entre duas e oito sílabas, entrecortam o ritmo do poema:

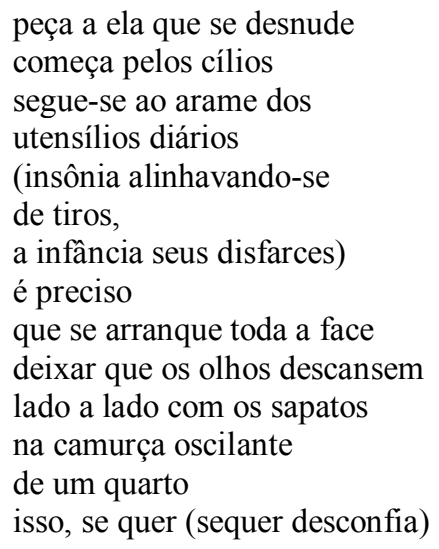


tocar o que se fia (um par

de presas, topázios)

entre os vãos das costelas

abra o fecho ela desfecha

no escuro o quadrante onde vaza

a luz e suas arestas

(DANIEL \& BARBOSA 2002: 100)

Ao recorrerem à fragmentação, os poetas o fazem para assimilar e modificar legados do passado, além de procurarem responder a desafios de seu tempo. Dialogam com a herança da fragmentação modernista que, por sua vez, reelaborava os primórdios das experiências fragmentárias na obra e na teoria românticas. Hugo Friedrich, que inclui a fragmentação entre as características negativas usadas não para depreciar mas para definir a lírica moderna, capta nessa poesia uma finalidade obscura, a de indicar "uma transcendência em dissonâncias e em fragmentos, cuja harmonia e totalidade ninguém mais pode perceber" (1991: 34). Se mesmo o desejo romântico pela unidade permaneceu sempre fragmentário, como mostra o jovem George Lukács em seu ensaio sobre Novalis ${ }^{2}$, nos poetas modernistas o sentimento da dispersão se eleva a horizonte existencial, qual em "Vontade de dormir", de Mário de Sá-Carneiro:

Fios de outro puxam por mim

A soerguer-me na poeira

- Cada um para o seu fim,

Cada um para o seu norte...

- Ai que saudades da morte...

Quero dormir...ancorar...

Arranquem-me esta grandeza!

Pra que me sonha a beleza,

Se a não posso transmigrar?...

(1995: 90)

Os autores modernos, conforme demonstra Raymond Williams através de Eliot, James Joyce e outros, tornaram-se responsáveis pela criação de uma imagística típica da consciência urbana, com repercussões decisivas sobre a própria escrita das narrativas e poemas (1990). Para Williams, Joyce é a realização mais acabada dos novos modos de percepção e identidade, alterados no espaço das cidades modernas. A originalidade de Joyce, seu modo de ver "fragmentado, promíscuo, isolado" concretiza-se em uma "nova estrutura da linguagem" (1990: 330).

A exposição sobre as relações entre modernismo e fragmentação, precisa conter ainda um outro elemento, de natureza formal, que desnuda o esforço dos líricos modernos em estabelecer elos entre o presente - o novo - e a tradição, simultâneo com as iniciativas de vanguarda. Ivan Junqueira registra essa prática multifacetada no estudo sobre a poética do fragmento, em Eliot, exemplar dentro do modernismo. Através dela, o poeta revitaliza materiais tomados de empréstimo a outros autores, entre eles Jules Laforgue, Dante, em termos de um "processo de eliotização" (JUNQUEIRA 1981: 18). Além dessa via intertextual, a técnica de fragmentação eliotiana tem outra, intratextual: ele reutiliza poemas seus, isolados, e faz dessas peças, nas suas palavras, "uma espécie de todo" (Junqueira 1981: 20). 
Os poetas atuais, que começaram a publicar entre os anos 80 e 90, retomam essas perspectivas modernistas da fragmentação, transformadas pelas poéticas do intermezzo: antilira cabralina, concretismo, poema-práxis, poema-processo, Tropicalismo e Poesia Marginal. Jogos lúdicos, enleios com a linguagem, e a esfinge da nova era em gestação renovam os sentidos de suas práticas fragmentárias. A lírica hesitante já tem os sinais dos anos 80, quando se intensificam no Brasil as repercussões do processo histórico da globalização. Na reflexão sobre as variadas narrativas e metáforas a respeito dos processos globalizadores, Néstor García Canclini (2003) lembra que esses surgem na segunda metade do século XX, após as etapas históricas da internacionalização (iniciada com as grandes navegações transoceânicas) e da transnacionalização da economia e cultura (a partir da primeira metade do século XX, quando as interconexões ainda traziam as marcas das nações originárias).

Interessa-me especialmente, em termos da teorização sobre fragmentação e poesia atual, lembrar que para Canclini a primeira é um traço estrutural dos processos globalizadores. O que se costuma chamar de globalização, ele afirma, "apresenta-se como um conjunto de processos de homogeneização e, ao mesmo tempo, de fragmentação articulada do mundo que reordenam as diferenças e as desigualdades sem suprimi-las" (grifo meu) (CANCLINI 2003: 44-45). Na procura de nomear os tempos atuais, a poesia da hesitação realiza sondagens, destinadas a falar do paradoxo de um mundo que se expande como uma grande cena da unidade permeada, infiltrada de processos fragmentários nos campos socioeconômicos e culturais. É o caso de Ausgang, de Age de Carvalho, em que a abertura, o caminho é, simultaneamente, diferentes conexões:

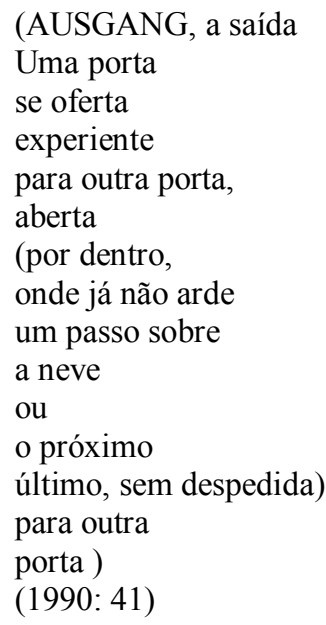

Situados entre as tensões redimensionadas do local/global, universal/nacional/tradição/atualidade, os poetas e narradores lidam com a composição de um novo texto. No trabalho criativo na Era das Reciclagens, eles vivenciam de modo intensificado o que Eni Orlandi detecta na relação texto-discurso: "não há discurso que produza um texto único, uma formulação só. Não há univocidade entre memória, discurso, texto. A incompletude se liga à dispersão" (2001: 135). Carlos Reis registra que estão sendo questionados os princípios de produção dos textos literários: o de estabilidade, o da coerência, o da linearidade, e o da discreção (este último, relacionado às fonteiras do texto). Conforme Reis, as características da escrita literária na era digital são: mais que textual, hipertexual; dinâmica, intertextual, interativa, lúdica, e 
fragmentária. Ele esclarece que o fragmentário vai se estabelecendo porque “ a propensão intertextual tende a revogar a coerência e a unidade dos textos" (REIS 2001: 12).

A baliza dos anos 80 - e aqui estou acompanhando a proposta de Pedro Lyra ${ }^{3}$ - indica que a lírica hesitante já tem uma geração de poetas formada, com produção em livro sobretudo a partir dos anos 90, e uma geração em seus começos, com lançamentos desde 2000. O gaúcho André Dick, que em 2002 surgiu com seu primeiro livro, Grafias, é um deles. Ao resenhá-lo, Paulo Ferraz afirma que o autor faz do mundo em fragmento a principal matéria de sua poesia, quer na forma, quer no conteúdo" (2003: 216). Posso acompanhar essa leitura de Dick se leio seu metapoema "Alguma palavra":

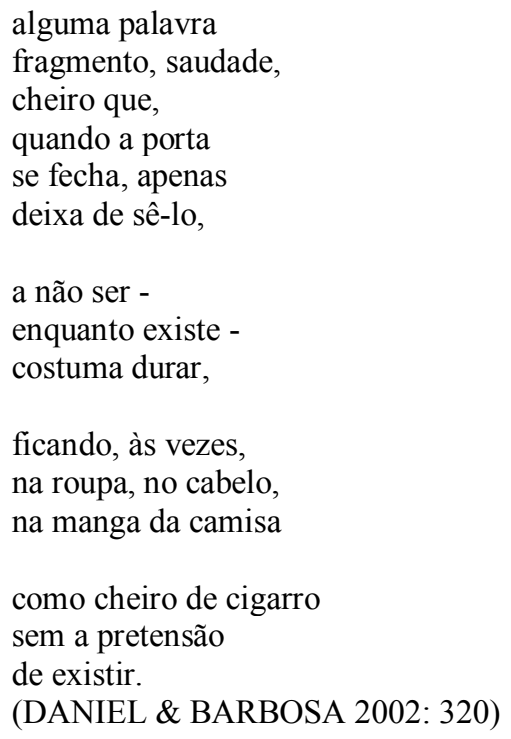

Os poetas hesitantes convivem na cena poética da atualidade com autores relacionados sobretudo ao código modernista, entre eles Lara de Lemos, Armindo Trevisan, Affonso Romano de Sant'Anna. Entre os hesitantes, a poética da fragmentação se alia a dois movimentos contemporâneos: o das hibridizações, intercâmbios; e os dos percalços para nomear sensações e sentimentos de eus cindidos, como se a poética da expressão se infiltrasse no arcabouço construtivista do poema. Na primeira vertente, o livro Nômada (2004), de Rodrigo Garcia Lopes, traz o poema "Arte do intervalo", que revela - motivo insistente na poesia da atualidade - a tentativa de nomear o que se encontra entre as palavras, entre as coisas e os seres, entre os tempos. É como se eu lírico estivesse buscando, não a Unidade, mas aquilo que, precariamente, estabelece pontes, interconexões:

O real não está nas coisas.

Nas coisas só existe a mente insaciável, analógica, ciosa: o que lhe interessa é o entre.

Ver é trans-ver, rever reflexos e oásis de passagens, não foto, vazios, paisagens, nexos 
para onde me transporto.

(LOPES s.p.)

$\mathrm{Na}$ via da expressão, a pena e as obsessões do amor são de-compostas na releitura, paródica, de Camões e Dante, em "Revisitando o Inferno na paixão", de Valdo Motta:

Em águas tantas vezes navegadas,

de dor em dor, no dia-a-dia, ser

o bêbado batel entre corais

(arrais e co-arrais já enjoados)

assim vagando em círculos, sem mais

combustível além do desespero

em águas tantas vezes navegadas. (HOLLANDA 1998: 299)

Indecisa, hesitante, a poesia brasileira atual assimila e renova a escrita literária, como se atendesse à reflexão paródica, provocativa, sobre a condição do poeta, em "Histórias de pescador", de Alckmar Luiz dos Santos:

Porém, se mostra e diz, é o que não há

- Que é dele o ofício, sempre, de enganar

Fazer que todo ouvinte vire anhoto -

E tudo que é exagero vem de par

Com a pouca, certa e vera história, mas

Sem ele, é vida, isso, esse assomo? (2001: 11-12)

\section{NOTAS}

\footnotetext{
${ }^{1}$ A pesquisa é desenvolvida, desde 2002, junto ao Mestrado em História da Literatura da FURG (Rio Grande - RS).

${ }^{2}$ Trata-se de "On the Romantic Philosophy of Life", de 1907. In: LUKÁCS, Georg. 1974. Soul and Form. London: Merlin Press. p. 42-54.

${ }^{3}$ A propósito da poesia brasileira do século XX, Pedro Lyra (1995) considera como gerações decisivas: Geração de 22, Geração de 45, Geração de 60 e Geração de 80.
}

\section{OBRAS CITADAS:}

CANCLINI, Néstor García. 2003. A globalização imaginada. São Paulo: Iluminuras. CARVALHO, Age de. 1990. Ror. São Paulo: Duas Cidades, Secretaria do Estado da Cultura.

DANIEL, Claudio \& BARBOSA, Frederico. 2002. Na virada do século: poesia de invenção no Brasil. São Paulo: Landy.

FERRAZ, Paulo. 2003. "Novíssima poesia brasileira: uma apresentação das poesias de Douglas Diegues e André Dick". Sibila, v. 3, n. 4, p. 210-223.

FRIEDRICH, Hugo. 1991. Estrutura da lírica moderna. São Paulo: Duas Cidades.

HOLLANDA, Heloisa Buarque de. 1998. Esses poetas: uma antologia dos anos 90. Rio de Janeiro: Aeroplano.

JUNQUEIRA, Ivan. 1981. "Eliot e a poética do fragmento". T. S. ELIOT. Poesia. Trad. Ivan Junqueira. Rio de Janeiro: Nova Fronteira. p. 11-48.

LOPES, Rodrigo Garcia. s.p. Nomadaversaoabril.doc.

LYRA, Pedro. 1995. Sincretismo: a poesia da Geração de 60: introdução e antologia. Rio de Janeiro: Topbooks.

LYOTARD, Jean-François. 1998. As regras da eficácia. Folha de S. Paulo (São Paulo), 11 out. Caderno Mais!, p. 11.

ORLANDI, Eni. 2001. "Boatos e silêncios: os trajetos dos sentidos, os percursos do 
dizer." Discurso e texto: formulação e circulação dos sentidos. Campinas: Pontes. p. 127-139.

REIS, Carlos. 2001. "Criação literária na Idade Digital." In: $4^{\circ}$ Encontro Nacional de Acervos Literários Brasileiros, 1999, Porto Alegre. Anais... Porto Alegre: CPLPUCRS.

SÁ-CARNEIRO, Mário de. 1995. Obra completa. Rio de Janeiro: Nova Aguilar. SANTOS, Alckmar Luiz dos. 2001. Rios imprestáveis. São Paulo: Lemos.

WILLIAMS, Raymond. 1989. O campo e a cidade: na história da literatura. São Paulo: Companhia das Letras. 


\title{
A IMAGINAÇÃO POÉTICA E O PROJETO ESTÉTITO DE LÍLIA A. PEREIRA DA SILVA
}

\author{
Antonio Donizeti da Cruz (UNIOESTE)
}

RESUMO: Este trabalho tem como objetivo apresentar o universo imaginário e o projeto estético de Lília A. Pereira da Silva, que revela um conjunto de imagens recorrentes em sua obra: mulher, espelhos, natureza, carnaval, palhaçoes, entre outras. Lília A. Pereira da Silva nasceu em Itapira (SP). É escritora, poeta, pintora, desenhista e ilustradora de livros. Tem publicado noventa e dois livros nas áreas de poesia, romance, literatura infantil, artes plásticas e didáticos. Como artista plástica e desenhista, ela tem realizado quase 300 mostras. Pretende-se analizar a obra da Autora, com fundamentação na teoria do imaginário, semiótica e mitocrítica. O universo imaginário, na obra de Lília, é espaço aberto no qual a poeta concretiza sua visão da vida e imagem do mundo. PALAVRAS-CHAVE: Lília Pereira da Silva - poesia - imaginário

"É pela intencionalidade da imaginação poética que a alma do poeta encontra a abertura consciencial de toda a verdadeira poesia". Gaston Bachelard.

Lília A. Pereira da Silva é escritora, poeta, pintora, desenhista, capista e ilustradora de livros. Publicou noventa e dois livros nas áreas de poesia, romance, literatura infantil, artes plásticas, didáticos de Direito, de Psicologia e Artes Plásticas. Alguns dos títulos publicados pela Autora:Desenho e Pintura (2002), Carnaval Brasil (1996, $2^{\text {a }}$ ed.), Elipses do anjo (1993), Cartas à minha sombra (1997), Álbum de mim nua (1997), Mínimos Conceitos (poesias) e Contos Abstratos(1994), Europeanas (1997, $3^{\mathrm{a}}$ ed.), entre outros. Lília A. Pereira da Silva nasceu em Itapira (SP). Reside em São Paulo. Foi professora de pintura e de piano, tendo participado de concertos. Cursou Secretariado, Jornalismo, Direito e Psicologia. Representou o Brasil em poesia, em Toluca (México), em 1972, e em Artes Plásticas, em Santiago (Chile), em 1974. Instituiu um prêmio anual, desde 1995, de Poesia e Desenho, com apoio da Prefeitura Municipal, Câmara Municipal de Esportes, Cultura e Turismo de Itapira, SP. Ilustradora e capista de livros nacionais e estrangeiros, Lília A. Pereira da Silva possui livros de suas poesias versadas em 8 línguas: inglês, francês, espanhol, italiano, japonês, latim, norueguês e alemão.

A artista Lília tem realizado quase 300 mostras (pintura e desenho). Recebeu um grande número de prêmios nacionais e internacionais (Battipaglia - Itália, México (D.F.), Roma, Paris, entre outros). Tem participado também de inúmeras antologias no Brasil e no exterior. Em relação às artes plásticas, suas obras encontram-se em museus brasileiros e estrangeiros (U.S.A, México, Holanda, França, Itália, Mônaco, Chile). Desenvolve uma técnica que vai desde o acrílico, esmalte, óleo, purpurina, colagem, tela, alumínio, papéis diversos, aquarela, ao guache (entre outros materiais). Suas obras vão do figurativo ao abstracionismo, revelando também ousadas técnicas expressionistas e surrealistas, com uma obra que revela manifestações e dramas humanos. 


\section{IMAGINÁRIO, POESIA E CONTEMPLAÇÃO}

A poesia e as artes em geral são potências capazes de dar sentido à vida. Ao buscar a essência da linguagem, o artista realiza o poder mágico através das palavras, das formas e cores: ser mediação, comunicação, exercício de construção de sentidos. Nesse sentido, Javier González afirma que a palavra é sempre uma "manifestação profunda do ser" (1990: 156). Para o autor, mediante o universo poético, o poeta se apóia nos aspectos lúdicos, rítmicos e imaginários da linguagem, cuja função poética funciona como um vetor constitutivo da natureza humana. É pela palavra que o homem se coloca no plano expressivo superior a não-significação da ordem natural, pois ela, enquanto núcleo de dispersão e convergência, é capaz de nomear o mundo (GONZÁLEZ 1990: 152-153).

González considera o trabalho do poeta como um desenvolvimento frente aos meios de fixação e dispersão de sentido, ou seja, como um jogo de palavras que tem por finalidade projetar um grande número de significações. Dessa forma, o escritor descobre e constrói o mundo utilizando a palavra enquanto instrumento "capaz de conter a surpreendente variedade do real", isto é, ele sabe que o uso da linguagem abre múltiplos espaços de "comunicação e de nominação dos objetos" (GONZÁLEZ 1990: 156-157).

Ao se referir à imaginação poética, Javier González salienta que as imagens têm sentido em distintos níveis, primeiramente, deve-se considerá-las autênticas e universais. Há as imagens arquetípicas que se revelam espontâneas e da mesma forma a todos os homens, ou seja, "são elementos fundamentais que podem descrever como categorias primárias da produção imaginária" (GONZÁLEZ 1990: 180). Existem ainda as que constituem uma realidade mental que se aproxima solidariamente aos objetos do mundo, isto é, elas constituem "um sistema cognitivo, com uma lógica particular. A seqüência das imagens, em contraste com o discurso, implica na equivalência das partes. Cada imagem constitui o universo em sua totalidade, e seus desdobramentos são um enriquecimento sobre o plano expressivo e não simplesmente informativo" (GONZÁLEZ 1990: 181). É dessa forma, no dizer do autor, que a relação analógica entre a imagem e o mundo fenomenológico confere àquelas um estatuto e forma um encadeamento semelhante às que unem as idéias e os conceitos no pensamento discursivo.

Para Javier del Prado, em Teoria y prática de la función poética: poesía siglo XX, a imaginação está limitada pela realidade, ou seja, "não se pode imaginar o que não existe; ela necessita de objetos, números, paisagens, planetas e se fazem precisas as relações entre os eles dentro da lógica pura. Não se pode saltar no abismo nem prescindir dos termos reais. A imaginação tem horizontes, quer desenhar e concretizar tudo que o que alcança" (PRADO 1993: 13).

No dizer de Prado, a imaginação poética viaja e transforma as coisas, lhe dá seu sentido mais puro e define relações que não se suspeitavam, mas sempre opera sobre fatos da realidade mais nítida e precisa (PRADO 1993: 13). E complementa:

Esta relação com a imaginação poética com a realidade e com a lógica, esta necessidade que tem a imaginação poética de concretizar e desenhar horizontes, permitem ao crítico 
[...] buscar referentes: pedras angulares no cruzamento de uma lógica ou uma analógica imaginárias que explicam, não as razões secretas (mistérios do eu criador sempre silencioso), mas sim os mecanismos e seus efeitos que têm como matriz a realidade e como semente fecunda e fecundante a imaginação poética (PRADO 1993: 13; grifos do autor).

Por sua vez, Luis Racionero, em El arte de escribir, salienta que o homem cria estruturas, relações, a partir de elementos preexistentes, pois a criatividade consiste em conectar estruturas mentais. Se uma conexão tal como se expressa mediante uma forma, causar emoção no espectador, se diz que é arte. A arte compõe entidades artificiais previamente inexistentes:golems de palavras, labirintos de imagens, mármores de pedra e cores, sons ou gestos, combinando esses materiais com o objetivo de intensificar a experiência e provocar profundas emoções para distinguir certas composições de ações fluentes, distinção que hoje em dia é mais necessária que nunca (RACIONERO 1995: 15-16).

Por se encontrar no nível mais alto da escala das experiências mentais, a imaginação, no dizer de Racionero, se forma a partir dos materiais proporcionados e armazenados por outros níveis: sensações oriundas dos sentidos, suas correspondentes imagens mentais, alucinações produzidas pela combinação errática destas no circuito neuronais e na memória. A imaginação criativa atua por onirosintesis (sonhos-síntese), nos lapsos da percepção, graças ao trabalho zelosamente oculto que se efetua na substância dos circuitos neuronais (RACIONERO 1995: 48-50). Por sua vez, a memória evoca imagens, a fantasia as combina fora das leis da natureza; a imaginação as molda em combinações orgânicas materializáveis na prática. A fantasia é uma simples justaposição de elementos incongruentes que formam uma quimera. Já o produto da imaginação contrasta com a realidade e por isso permanece e dura. A fantasia é a combinatória da imaginação, salienta Racionero.

Para Gaston Bachelard, a imaginação não é, como sugere a etimologia, "a faculdade de formar imagens da realidade; é a faculdade de formar imagens que ultrapassam a realidade, que cantama realidade" (1989: 18; grifo do autor). Mais do que inventar coisas e dramas, a imaginação "inventa vida" e "mente novas". O filósofo define a imaginação como uma potência máxima da natureza humana. A imaginação, com sua "atividade viva", desvincula-se, simultaneamente, do passado e da realidade, direcionando-se para o para o futuro. Nesse sentido, a "fenomenologia da imaginação" não se contenta "com uma redução que transforma as imagens em meios subalternos de expressão". Ela "exige que vivamos diretamente as imagens, que as consideremos como acontecimentos súbitos da vida. Quando a imagem é nova, o mundo é novo" (BACHELARD 1993:

$63)$.

Gilbert Durand define o imaginário como o "conjunto das imagens e relações de imagens que constitui o capital pensado pelo homo sapiens" (1997: 18). Ele é o grande denominador fundamental para onde se convergem "todas as criações do pensamento" (DURAND 1997: 18). O filósofo salienta ainda que, o imaginário humano constitui o conector inevitável pelo qual se forma qualquer representação humana, pois "todo pensamento humano é uma $r e$-presentação, isto é, passa por articulações simbólicas" 
(DURAND 1997: 40-41; grifos do autor). Complementa ainda que, o imaginário institui a priori um "domínio do espírito sobre o mundo", sendo que,

É a objetividade que baliza e recorta mecanicamente os instantes mediadores da nossa sede, é o tempo que distende a nossa saciedade num laborioso desespero, mas é o espaço imaginário que, pelo contrário, reconstitui livremente e imediatamente em cada instante o horizonte e a esperança do Ser na sua perenidade. (DURAND 1997: 433)

Já as imagens, qualquer que seja "o regime a que pertencem, em contato com a duração pragmática e com os acontecimentos, organizam-se no tempo, ou seja, ordenam os instantes psíquicos numa "história"” (DURAND, 1995, p. 75-76. Grifo do autor).

Se a imaginação é a força dinâmica pela qual o homem consegue imaginar mundos e dar sentido à vida através de imagens, a poesia é o vetor de operacionalização dos instantes vividos, das transmutações da linguagem, da valorização dos sentimentos e das coisas mais simples. É por meio da imaginação e da concretização da poesia que o ser humano consegue dar forma às coisas mais tênues, evanescentes e se auto-afirmar. Sendo assim, a poesia é transcendência, contemplação, força que edifica e revigora o homem frente às vicissitudes da vida.

\section{LIRISMO, VIAGEM E IMAGINAÇÃO POÉTICA EM EUROPEANAS}

A obra Europeanas, de Lília A. Pereira da Silva, reúne 31 poemas que remetem a uma variedade temática que vai do tema da viagem à memória e imaginação. Já os registros feitos pelo sujeito lírico realçam a condição de um eu que observa o mundo, as coisas, as cidades, campos, pessoas e praças e, ao mesmo tempo, revela-se ao refletir sobre a vida, o olhar e a observação atenta da natureza. $O$ tema da viagem é alicerçado por um Eu que vai registrando as paisagens européias e as cidades: Paris, Madri, Sevilha, Lisboa, Roma, entre outras.

Ao se referir a Europeanas, de Lília A. Pereira da Silva, o escritor francês Claude Cotti, afirma que "Ler Europeanas é viajar para onde ela andou na Europa. Suas poesias são fortes e inesquecíveis, como toda Literatura. Tem-se a impressão de estar vendo telas a óleo, coloridas e musicadas, em cada poesia de seu livro" (COTTI, in: SILVA 1997: contracapa). E complementa: Ela levou o Brasil à Europa e a Europa ao Brasil. Assim, fala [...] da sua muita esperança, da presença dos deuses, da saudade do irmão morto, do Museu do Prado, do Mediterrâneo e Adriático e "esquece as sandálias brancas na rua de Madri, onde perambula com versos de Florbela e de Pessoa". Cita as "Capas de Coimbra, os mochileiros tatuados, os toureiros, Picasso", tudo "ardendo um perfil na sua bandeira brasileira". (COTTI, in: SILVA 1997: contracapa)

Claude Cotti destaca ainda que a maior parte das poesias de Europeanas foram escritas no Café de La Paix, em Paris. Cumpre destacar que o poeta francês traduziu por duas vezes os poemas de Lília. Lília A. Pereira da Silva tem recebido crítica favorável à sua obra de poetas, críticos, artista plásticos, brasileiros e internacionais. Ela tem recebido elogios de Fernando Namora, Carlos Drummond de Andrade, Wilson Martins, entre outros. Sobre Lília, Cecília Meireles afirma: "Lília - a de olhos guardados nas rosas..." ( SILVA 1991). 
Segundo João Alexandre Barbosa, a viagem - para o poeta moderno - não significa somente uma conquista cumulativa de espaços inusitados, mas "a criação de um espaço em que seja possível reduzir a multiplicidade individual da linguagem da poesia aos parâmetros homogêneos da linguagem do poema" (1986: 32). Barbosa lembra que "viagem é linguagem", e destaca que o poeta moderno é sabedor de sua condição de iludido, pois "a procura da consciência nostálgica da eternidade" faz com que ele se lance na busca da conquista do intemporal, porém se vê frente ao transitório, ao fugidio e ao contingente. Ele se imagina intérprete do Homem, e não dos homens, pelo cultivo de uma outra ilusão: a da onipresença.

O motivo da viagem - recorrente na obra Liliana - direciona para uma linha da literatura ocidental que remete à Odisséia de Homero, passa pelas aventuras de Dom Quixote, pelas literaturas de viagem e por tantas outras que tratam desta temática. A viagem na obra de Lilia A. Pereira da Silva tem, muitas vezes, o sentido de travessia e também "introspecção", em que o eu-lírico "mergulha" em si mesmo em busca do eu totalizante. Na circularidade do tempo e do espaço, o sujeito poético faz da viagem convite à busca de sentido vital e descobertas das "paisagens do mundo". Através das palavras, concretiza-se uma "viagem" em que os espaços vazios são preenchidos pelas palavras e sentidos de "travessia", tal como nos versos do poema "Passagem":

$\mathrm{Eu}$, de passagem,

passando.

Só não passa a poesia

- porto de muitas viagens,

gosto de estrelas feridas.

(SILVA 1997: 32).

A palavra "viagem" é termo que aparece com freqüência na obra de Lília A. Pereira da Silva, de maneira especial em Europeanas. O sujeito poético, nos versos, concretiza seu estar no mundo e faz do ato de viajar uma potência criadora de descobertas, desvendando espaços inusitados, tal como nos versos do poema "Travessia do Sena", em que o eu-lírico expressa a condição de observador atento:

Barco é altar no Sena,

Derruba lenda, a estrela,

no suportável das margens.

$[\ldots]$

Mais lampiões sobre as pontes,

ancoradouro, partida.

Faróis tingindo de verde

mansas águas que se singra

(espuma de vime e junco).

Canções de ausência mais claras...

E que trêmulo ombro

ampare outro que tenho

nas travessias futuras...

(SILVA 1997: 61-63)

Em "Retrato plural", o eu lírico realça a constatação de que as cidades são parecidas, 
quer no espaço urbano, na geografia, no comportamento das pessoas, na observação atenta das coisas e nas imagens reiterativas, com versos repletos de lirismo:

Em todas as cidades do mundo,

sofrimento é maior quando não se perdeu

coração em ninguém.

Em todas cidades do mundo,

há roupas estendidas nas paredes

e nudez dentro

das vidraças.

$[\ldots]$

Em todas cidades do mundo há espaços, muros

e sapatos abandonados nas ruas,

tirando retratos do passado

e futuro,

e pombas que exibem asas

e não voam - como outras - acima dos telhados.

Em todas cidades do mundo

há janelas sujas de trem

anuviando paisagem,

$[\ldots]$

Em todas cidades do mundo há ciganos

que revivem esta saudade,

estalando

no meu céu da boca

o grito da vida.

[15.07.88 - De Lisboa a Fátima (SILVA 1997: 7-8)]

O poder da imaginação que direciona a uma abrangência mais ampla, é a tônica que movimenta o poema. Em todas as estrofes, destacam-se os paralelismos sintáticosemântico-sonoros das estrofes iniciadas pelo verso: "Em todas as cidades do mundo". Há a constatação por parte do eu lírico de abandonos, saudades, sofrimentos, contrastes.

Operador de enigmas, o poeta faz da linguagem um espelho de dupla face: de um lado a palavra e do outro o silêncio. Na conjugação das formas dialéticas ele constrói o universo imaginário em que é possível a realização, daí a linguagem do poema ser "revelação". Quer dizer, "a revelação poética pressupõe uma busca interior. Busca que em nada se assemelha à análise ou à introspecção, mais que busca, atividade psíquica capaz de provocar a passividade propícia ao surgimento de imagens" (PAZ 1982: 65).

No poema "Gaivota", o tema da viagem fica latente:

Também pode a gaivota ter mais sonhos:

auréola de pastora, inda vencer

o barco espumarando verde mar.

Constelada de ânsias,

o leme escorre às asas.

Entanto, 
esvoaça-lhe o motor a própria sombra.

Limitada no ser,

inquieta, não sinala porto íntimo,

mas glória de tentar lhe foi cumprida.

[18.07.88 Aeroporto de Lisboa (SILVA 1997: 12)]

Nos versos sobressaem as imagens do "porto", "barco", "gaivota", "mar". São versos marcados por uma linguagem que revela a condição de um eu lírico enquanto observador atento e em constante viagem. Na primeira estrofe, a afirmação do sujeito lírico é categórica ao reportar à gaivota capaz de alçar vôos e sonhar, até mesmo vencer "o barco espumarando verde mar". A segunda estrofe alude à observação atenta da natureza com seus signos vitais, ou seja, as imagens do "leme" e das "asas" fazem alusão à viagem. Na última estrofe a constatação de que a gaivota, mesmo "limitada no ser" é capaz de atingir o mais alto objetivo. A imagem da gaivota - enquanto metáfora pode remeter à condição itinerante do ser humano, "sempre em viagem".

Percebe-se que a poesia liliana reside na busca memorável e densa das palavras e na concretização de um fazer poético enquanto "felicidade da expressão verbal", no dizer de Calvino, que pode efetivar-se mediante "uma fulguração repentina", em alguns casos, mas na maioria das vezes, tal processo implica sempre em "uma paciente procura do mot juste, da frase em que todos os elementos são insubstituíveis, do encontro de sons e conceitos que sejam os mais eficazes e densos de significado" (CALVINO 1990: 61; grifo do autor). Dessa forma, o fazer poético liliano está embasado, essencialmente, na busca da palavra exata para concretizar a comunicabilidade lírica.

No poema "Chovem lírios em meus cabelos", com uma linguagem altamente elaborada, registra os momentos vivenciados pelo sujeito da enunciação:

Chovem lírios em meus cabelos

e é grave a urze no peito.

Nas fontes de pedras,

emoções deliram

em outras línguas.

Existe fantasia e realidade:

pesadas estátuas

em tênue fio unidas.

Canta no palácio, a menina.

Velha senta na calçada:

gume e flor.

Cisma o Tejo, dorme o Sena, ora e canta Manzanares, rendam-se em rosas de gotas, Mediterrâneo e Adriático.

Vestindo espadas, bandeiras arcoirisando olivais, mulheres de sete saias no bairro das Mourarias cheiram fado nos cabelos, vestem xales de saudade. [...] 


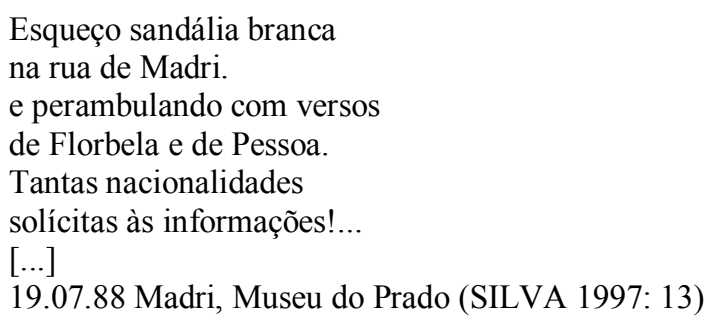

Note-se, nos versos, uma linguagem metafórica, com imagens sugestivas: "chuva de lírios nos cabelos", "urze no peito" e "cheiro de fado nos cabelos". Há a descrição geográfica de lugares europeus, como o bairro da mouraria, referências aos rios Tejo, Sena, Manzanares, e aos mares Mediterrâneo e Adriático. A personificação é um recurso utilizado pela poeta para realçar e dar dinamismo ao texto.

As rimas, na poesia de Lília A. Pereira da Silva, são recursos fundamentais que suscitam inesperadas alianças de termos, de sentido. Não se trata apenas da sonoridade, musicalidade, mas o que está em jogo é a estrita relação entre som e sentido.

O poeta, através do ato de nomear, de poetizar o mundo e de dar sentido às coisas, faz da linguagem uma viagem em versos. Mediante a atividade criadora, o poeta, enquanto viajante no e do mundo, reafirma sua condição de exilado. Daí a poesia auxiliar o homem no esclarecimento de uma das questões psicológicas mais relevantes: "a determinação do seu próprio ser" (LOTMAN 1978: 119-23). Note-se, nos versos, um sentido vital no que diz respeito à construção do texto relacionada ao jogo de palavras projetando uma "poesia-invenção" que veicula o máximo de informação em um número restrito de palavras.

No poema "Madri", o sujeito da enunciação observa a paisagem e referências citadinas:

Madri no rastro do poente.

Primavera

em meus cabelos brancos...

Inda cantam

as capas de Coimbra

e ciganas de negro,

retratando lâminas

nas mãos.

Mochileiros tatuados

entre xales e babados.

Mulheres jovens,

exaustas de emoção.

$[\ldots]$

Toureiros brilham ouro nos brincos,

entre sirenas.

[...]

Cisnes comungam peixes pelas praças,

sem mais o Douro

esvoaçando

à vidraça.

Estrela morde o dia.

Picasso mostra homens por dentro. 
$[\ldots]$

Aqui, como em toda cidade do universo, atenta às manhãs e madrugadas, resumo que poetas e heróis só valem se em morte resumidos.

[20.07.88 Caminho para Toledo, Espanha (SILVA,1997: 16-17)]

Note-se, nas passagens, a essência fundamental da poesia liliana, que reside na harmonia e na beleza com que organiza seus poemas, quer dizer, nesse "universo" de relações recíprocas entre os "sons" - a musicalidade, o ritmo, o movimento, o timbre, a entonação, a voz transmudada em ação - e os "significados" - as idéias, as imagens, as excitações do sentimento e da memória e as formações de compreensão, como nos versos: "Estrela morde o dia", "Touros brilham ouro nos brincos", "Cisnes comunga peixes nas praças". Através dessas relações, o poeta cria seu universo poético operacionalizando a linguagem no sentido de que fala Paul Valéry: o poema "não morre por ter vivido: ele é feito expressamente para renascer de suas cinzas e vir a ser indefinidamente o que acabou de ser. A poesia reconhece-se por esta propriedade: ele tende a se fazer reproduzir em sua forma, ela nos excita a reconstruí-la identicamente" (VALÉRY 1991: 213).

Em "Flash de mim na estrada", o tema da viagem mais uma vez ganha dimensão na enunciação do sujeito lírico:

Percebo, no infinito,

tantas cismas comovidas;

ando por onde não fui

e fui por onde não ando!

Estremeço em cada passo, nos pedaços da estrada, somada de tantos auges, ao próximo adaptada.

Viajo como em mim, no mistério de mil quilhas, vendo hoje, vendo ontem e só de mim não segura - indefinido prenúncio de que sou muito e sou nada.

Se me enfeitam saudades, mais me enfeitam estradas. Em mim murmura volúpia das coisas apagadas

Hoje fui um girassol; a manhã, rosa-dos-ventos. Já fui deserto e fui água. Só não fui a que não sou. E não serei apagada.

25.07.88 Caminho para Granada (SILVA 1997: 28)

São versos que remetem ao tema da viagem enquanto busca e que mostram a imaginação do sujeito poético, capaz de articular a linguagem de maneira lúdica. Há, 
nos versos, o sentido de procura: o eu em busca de si mesmo e do outro. O sujeito lírico expressa sua condição de viajante solitário, ao declarar que viaja "no mistério de mil quilhas, / vendo hoje, vendo ontem / [...] - indefinido prenúncio / de que sou muito e sou nada." (SILVA 1997: 28).

O universo poético liliano articula-se através da multiplicidade das imagens de um eu que se desdobra verso a verso, das imagens e figuras densas, das consonâncias e dissonâncias dos versos com seus ritmos bem acentuados.

O tema e o movimento vital da viagem - na obra Lília A Pereira da Silva - faz com que o sujeito poético se volte ao tempo passado e também se lance ao tempo futuro. Para Erico Verissimo, o ser humano viaja por dois motivos básicos: "para fugir ou para buscar. Os fugitivos cedo ou tarde descobrem que seus problemas são de natureza geográfica" (VERISSIMO 1999: 145). Nesse sentido, a viagem não é só um processo de redescoberta, mas uma experiência que se realiza no plano pessoal e espacial.

Mediante o ato imaginativo, Lilia A Pereira da Silva concretiza uma poesia que é mediação solidária com o leitor, ou seja, sua voz "participativa" abre múltiplos espaços de interlocução. A poesia liliana aponta para a experiência cotidiana e transcende-a mediante a imagem poética, que se reporta a uma dimensão maior, despertando no leitor um sentimento de plenitude e fascinação perante as palavras. Assim, a poesia é uma forma de auto-revelação, que permite um constante "recriar-se e recriar-nos", pois conforme Octavio Paz, ela "é um tecido de conotações, feita de ecos, reflexos e correspondências entre som e sentido" (1991: 151). Esta afirmativa do autor pode ser constatada no poema "Passagem", em que o eu-lírico afirma:

Sol de estanho na cama e meu cavalo de sombra. Estrelas de pergaminho e reluzente carinho na minha pele tão só.

Sol de estanho na cama e meu cavalo de sombra. Ao longe, flauta entornada, ébrios pandeiros ciganos em pátios só muçulmanos em Alicante e Granada.

Sol de estanho na cama e meu cavalo de sombra. $\mathrm{Eu}$, de passagem, passando.

Só não passa a poesia - porto de muitas viagens, gosto de estrelas feridas. [27.07.88 Caminho para Valença (SILVA 1997: 32) ]

Os versos realçam a temática da viagem, que remete ao sentido de introspecção, de subjetividade e busca de si mesmo. Na esfera vital, de tantas travessias, o eu se desdobra verso a verso, num esforço de autocompreensão realizando uma viagem que se processa na busca de si mesmo e na busca do outro. Viajar por mundos imaginários é uma 
maneira de amenizar "as paisagens do mundo" nem sempre belas, nem sempre harmoniosas.

A poesia é definida como "porto de muitas viagens". Da imaginação do poeta surge uma linguagem metafórica, lúdica, como nos versos:

\section{Sol de estanho na cama e meu cavalo de sombra. Estrelas de pergaminho e reluzente carinho na minha pele tão só.}

Na passagem fica evidência a solidão vivenciada pelo eu lírico. Já o poema - sinal de "quase-permanência" num mundo transitório - acaba por ser expressão da consciência de um sujeito que faz da imaginação uma viagem inusitada através da linguagem. $O$ poeta se volta à experiência poética no afã de atingir o equilíbrio e a contenção da linguagem, pois na procura mais essencial da palavra para transmitir uma emoção, ele nomeia as coisas criando uma nova realidade. No poema "Toureiro descalço", as imagens do touro e da noite aparecem interligadas:

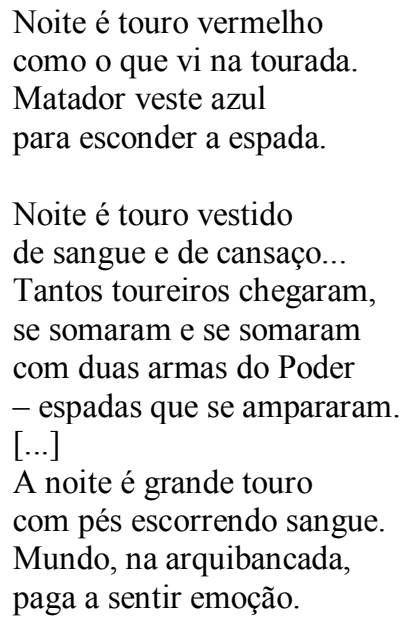

Só touro não entende palmas que são para ele morrer.

Ai, toureiro! Em tua capa são micas chifres de touro e tento não padecer!...

Noite é touro vermelho Como o que vi na tourada... [28.07.88 Caminho para Barcelona (SILVA 1997: 33-34) ]

As imagens da noite, touro e toureiro são realçadas no texto. A noite (metáfora de morte) é definida como "touro vermelho". Há o contraste das cores azul e vermelho: toureiro (matador) vestido de azul X noite vestida "de sangue e cansaço". Conforme Chevalier e Gueerbrant, a imagem do touro "evoca a idéia de irresistível força e arrebatamento" e é símbolo da "força criadora" e é considerado, portanto, "um animal lunar, relacionado com a noite" (2002: 890-892). Note-se que a imagem é "palavra articulada", no dizer de Alfredo Bosi. Assim, touro e noite estão (inter)relacionadas no 
poema (BOSI 2000: 19). Para Bosi, a imagem "é afim à sensação visual. O ser vivo tem, a partir do olho, as formas do sol, do mar, do céu. O perfil, a dimensão, a cor. A imagem é um modo da presença que tende a suprir o contato direto e a manter, juntas, a realidade do objeto em si e a sua existência em nós" (BOSI 2000: 19).

No poema "Elos", as confluências de vozes ficam evidenciadas. O poema apresenta a cidade de Florença "acordada de sinos", a voz do camelô: "Loteria de Veneza", e a firmação do eu lírico ao dizer que passou o "domingo escrevendo / nos túneis voadores". Há também as lembranças de Barcelona, dos "mercadores de pássaros", "a orelha cortada de touro", e a ampla geometria das coisas e descrição dos lugares, como nas passagens:

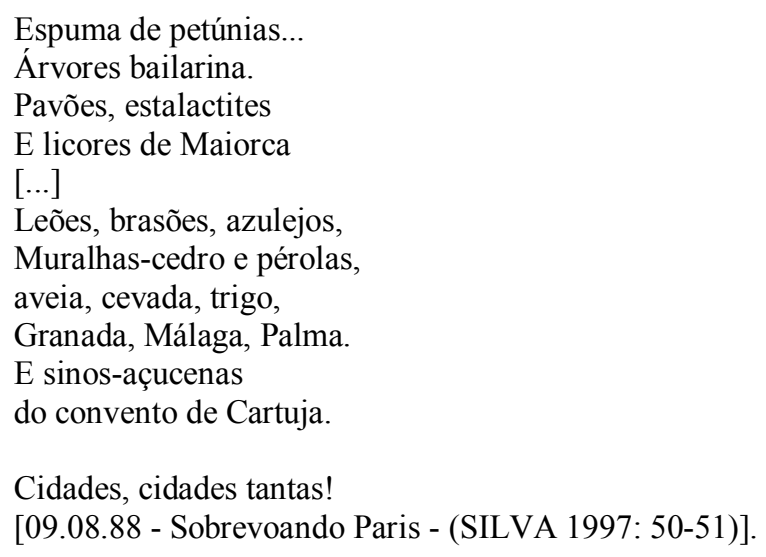

As imagens, nos versos dos poemas, direcionam, muitas vezes, para as coisas que só uma mente aberta à contemplação da natureza pode observar. Das impressões de viagens e dos registros de novas descobertas pelo sujeito lírico por estar conhecendo tantas cidades européias, faz a seguinte afirmação:

Também tenho uma cidade

que é cela das estrelas

do pensamento só meu.

No seu eixo imaginário,

tem balcão de arcanjo.

E se a seara é errante,

vive a alfazema do instante

de apagadas arenas.

Uma característica peculiar da poeta Lília é sua disciplina espiritual, sua maneira de ver o mundo com "os olhos da imaginação". Ao projetar sua consciência artística, em que reúne técnica poética aliada a uma inteligência crítica, ela dá forma e procedimento artístico e poético à sua arte.

Os versos do poema "Imagem", realçam a questão do olhar e das coisas que ocorrem ao redor do sujeito lírico atento às paisagens:

Ai, castanholas de sóis

e rosas de fel na boca!

$\mathrm{Ai}$, viagens ao redor

da janela que não eu!... 
Convencer-me a cada instante que, em toda despedida das cidades que conheço, um fim pode ser começo!..

\author{
Ai Múrcia, mica e verde, \\ distante das odaliscas, \\ leões, sultões, magnólias, \\ tanto oásis de Granada! \\ Onde guitarras ébrias \\ de fantasmas e fantasmas \\ e poesias escritas \\ nas paredes de Alhambra?
}

Ai, tempo que faz promessas, ai, tempo que faz surpresas! Às vezes abraço o sol, às vezes cai minha estrela!... [03.08.88 Roma (SILVA 1997: 33-34)]

A repetição do tema da viagem aponta para a esperança e certeza de que as palavras têm o poder de despertar o homem para o sonho, para iniciar a busca e chegar à realização, mesmo que, às vezes, o tempo traga "promessas" e "surpresas. A remissão constante ao tema da viagem relaciona-se à procura do eu em permanente busca de si mesmo, reporta às mais diversas formas de desdobramento do sujeito lírico sempre à procura de algo que dê sentido à vida, tal como afirma o sujeito lírico, nos verso do poema "Gosto de cicatriz": "Perto de mim, sem viver, / esta busca, esta busca / e gosto das cicatrizes / das batalhas invisíveis / que só o silêncio as tem" (SILVA 1997: 49). A poeta projeta um mundo de descobertas e experimentações com a linguagem, feita de sons, silêncios e sentidos.

A temática da viagem, na poesia de Lília A Pereira da Silva, remete para a busca e para a redescoberta de um centro espiritual. A viagem simboliza a busca do plano transcendente. Exprime ainda, "um desejo profundo de mudança interior, uma necessidade de experiências novas, mais do que um deslocamento físico. Segundo Jung, indica uma insatisfação que leva à busca e descoberta de novos horizontes" (CHEVALIER \& GHEERBRANT 2002: 952).

A viagem - na poesia Liliana - ocorre enquanto busca, isto é, expressa todo um sentimento e toda uma afirmação do sujeito poético ao se situar no tempo e espaço. Através da viagem em versos e das operacionalizações articuladas pela linguagem, o poeta se vê inserido nas múltiplas facetas espaço-temporais. A viagem ganha, assim, uma dimensão de destaque de um eu que está em "viagem" permanente.

Em Europeanas, há um universo de recordações que apontam para lugares e espaços vitais. Através da linguagem poética, enquanto viagem e travessia, Lília A. Pereira da Silva rememora impressões de viagens e recupera fatos e momentos vividos no exercício poético e imaginário.

Na obra de Lília A. Pereira da Silva, as formas do imaginário não são simples temas. Elas ocorrem entrelaçadas quer às obras literárias quer às pictóricas no universo liliano, 
que registra imagens alicerçadas nos "registros-chave", que direcionam para um cuidadoso processo de escritura e elaboração "poético-pictórica" alicerçados na imaginação poética.

Pode-se concluir que a construção poética e o projeto estético liliano residem nos procedimentos e nas formas escolhidas, nos ritmos, no enxugamento dos textos, "nas pinceladas poéticas" de palavras, cores e formas. Seus poemas registram o teor de modernidade e contemporaneidade. Na poesia de Lília verifica-se a preocupação do eu poético em relação à elaboração precisa da linguagem, registrada na maneira de interpretar o mundo e as coisas. Com sua maneira própria de atuação, a poeta apresenta $\mathrm{o}$ ato criador como um exercício e comprometimento perante a vida e a arte, mediante a efetivação de um pensamento capaz de (re)inventar universos imaginários.

\section{OBRAS CITADAS:}

BACHELARD, Gaston. 1989. A água e os sonhos: ensaios sobre a imaginação da matéria. São Paulo: Martins fontes.

—. A poética do devaneio. São Paulo: Martins Fontes.

BARBOSA, João Alexandre. 1986. As ilusões da modernidade. São Paulo:

Perspectiva.

BOSI, Alfredo. 2000. O ser e o tempo da poesia. São Paulo, Companhia das Letras.

CALVINO, Ítalo. 1990. Seis propostas para o próximo milênio. São Paulo: Companhia das Letras.

CHEVALIER, Jean \& GHEERBRANT, Alain. 2002. Dicionários de símbolos. Rio de Janeiro: José Olympio.

DURAND, Gilbert. 1995. A imaginação simbólica. Lisboa: Edições 70, 1995.

—. 1997. As estruturas antropológicas do imaginário: introdução à arquetipologia geral. São Paulo: Martins Fontes.

GONZÁLEZ, Javier. 1990. El cuerpo y la letra: la cosmología poética de Octavio Paz. México: Fondo de Cultura Económica.

LOTMAN, Iuri. 1978. A estrutura do texto artístico. Lisboa: Editorial Estampa.

PAZ, Octavio. 1982. O arco e a lira. Rio de Janeiro: Nova Fronteira.

- 1991. Convergências: ensaios sobre arte e literatura. Rio de Janeiro: Rocco.

PRADO, Javier del. 1993. Teoria y prática de la función poética: poesía siglo XX.

Madrid: Cátedra.

RACIONERO, Luis. 1995. El arte de escribir: emoción y placer del acto creador.

Madrid: Temas de Hoy.

SILVA, Lília A. Pereira da. 1991. 33 anos de poesia. São Paulo: Scortecci.

—. 1996. Carnaval Brasil / Carnival Sketches. São Paulo: Scortecci.

—. 1997. Europeanas. São Paulo: Scortecci.

VALÉRY, Paul. 1991. Variedades. São Paulo: Iluminuras.

VERISSIMO, Erico.1999. A liberdade de escrever: entrevista sobre literatura e política. São Paulo: Globo. 


\title{
A MÁQUINA DO POEMA \& A MÁQUINA DO MUNDO: PRIMEIRO ESBOÇO PARA UMA POÉTICA
}

\author{
Antonio Donizeti Pires (UNESP/Araraquara)
}

RESUMO: O presente trabalho objetiva refletir os temas, motivos, mitos, personagens e figuras históricas que migram de uma literatura a outra; ou da literatura erudita para o oral; ou desta para aquelas. O estudo privilegia poesia lírica e vale-se das teorias da literatura comparada e da intertextualidade, da metaliguagem e das artes poéticas - de "escola" ou "pessoa" -, não negligenciando asectos como o conceito de gêneros literários e questões sócio-culturais. Para o momento, refletir-se-á acerca da máquina do poema como emblema da máquina do mundo, conforme plasmada pelos poetas Dante Alighieri, Luís de Camões, Drummond, João Cabral e Haroldo de Campos.

A Universal machina do Mundo se divide em duas partes: Celestial \& elemental.

"Pedro Nunes, Tratado da Sphera (século XVI)

E desse nó a forma universal creio ter visto

Dante - "Paraíso", XXXIII. 91-92

Vês aqui a grande máquina do Mundo, Etérea e elemental

Camões, Os Lusíadas, canto X. 80:1-2

E como eu palmilhasse vagamente uma estrada de Minas, pedregosa, $[\ldots]$ a máquina do mundo se entreabriu para quem de a romper já se esquivava...

Drummond, "A máquina do mundo"

46.2. ninguém fala hoje em dia em maquinária 46.3. do mundo concentrando continentes Campos, A máquina do mundo repensada

$\underline{\mathrm{Um}}$

A compreensão do poema como máquina, ou seja, como objeto construído de linguagem, baseado em leis próprias de composição, já está presente em poetas da Idade Média, do Maneirismo, do Barroco e da modernidade (os românticos alemães, Poe, Baudelaire, Mallarmé), mas é no século XX que tal idéia se acirra. No Brasil, além dos exemplos de Haroldo de Campos e Mário Faustino, entre outros, penso que foi João Cabral de Melo Neto quem mais explorou, de maneira original e radical, a noção do poema como máquina, conforme patenteia a seguinte entrevista do poeta aoJornal de Letras e Artes, de Lisboa, em junho de 1966:

Somos gente de muita textura e pouca estrutura... Eis a razão de meu interesse sempre crescente - desde Serial e Quaderna - pela máquina do poema. A imagem forte 
interessa-me cada vez menos. Durante os anos mais próximos irei ainda explorar o ensemble da composição. (NUNES 1976: 266; grifos do autor)

A maneira como o poeta concebe a metalinguagem e a metapoesia - ao lado de seu trabalho com a linguagem, de sua consciência construtiva, da escolha de seus temas, de sua recusa da "imagem forte" e de sua obsessão pelo exato, pelo claro e pelo contundente -, é em larga medida responsável pela configuração de seu poema como máquina. Conforme afirma João Alexandre Barbosa, a metalinguagem cabralina ultrapassa o tópico simples da poesia sobre poesia e instaura um embate tenso entre a realidade e a expressão dessa realidade pela poesia. Trata-se, de acordo com o crítico, de uma metalinguagem fundante, "que recusa o fácil, o que flui, aquilo que foge do controle da máquina do poema" (BARBOSA 2002: 273), ao mesmo tempo evidenciando que as relações entre realidade e poesia "são antes de tensão e de procura de traduções estruturais do que descritivas, quer disfóricas, quer eufóricas ou apologéticas" (BARBOSA 2002: 284). Trata-se, ainda, de uma "metalinguagem [que] não se esgota em si mesma", que opera sempre como "um instrumento pelo qual [o poeta] vai descobrindo ou recriando a forma das coisas" (BARBOSA 2002: 283) e onde se revela "a persistência de uma meditação acerca da criação poética que se dá na própria composição" (BARBOSA 2002: 298). Metalinguagem, em suma, que "ao mesmo tempo que diz da realidade, diz também de uma maneira específica de sua apreensão pelo poema" (BARBOSA 2002: 299).

Encarecido por Barbosa nos ensaios citados, "A lição de João Cabral" e "A poesia crítica de João Cabral" (ambos reunidos em Alguma crítica, 2002), o exemplo cabralino referenda, em minha opinião, a compreensão profunda que se deve ter da prática metalingüística. Esta não pode ser tida apenas como modismo, como algo fortuito e exterior ao poema, mas como uma das bases fundamentais em que se assenta toda poesia realmente crítica e consciente. Enfim, a prática da metalinguagem e da metapoesia - objeto de teorização recente talvez porque levadas às últimas conseqüências apenas com os poetas da modernidade -, ao exacerbar a consciência crítico-construtiva do poeta e tornar-se fator de valoração e valorização da poesia moderna e contemporânea, ressalta, ao mesmo tempo, que a máquina do poema alimenta-se também de poesia: pois a auto-reflexividade, a auto-referencialidade, a consciência construtiva, o pensar sobre a linguagem, o poema, o poeta e a poesia; em suma, o voltar-se sobre as próprias engrenagens, revelando a concepção engenhosa que a norteia, é um dos movimentos preferidos da máquina do poema.

$\underline{\text { Dois }}$

O tópico da máquina do mundo, como tantos outros topoi velhos conhecidos nossos (o carpe diem, o convite amoroso, o retrato feminino, o ubi sunt?, a roda da fortuna, o universo como livro ou o livro como universo, o não sei quê, a vida como sonho, o mundo como teatro, o mundo às avessas ou em desconcerto etc.), foi aproveitado pela poesia de todos os tempos de maneira bastante variada. Presente entre os gregos e os romanos (Pitágoras, teórico da harmonia, fez com que as sete cordas da lira correspondessem às sete esferas celestes; Publius Terentius Varrus, herdeiro da tradição pitagórica, legou-nos o poema geográfico Corografia, onde vislumbra o giro da terra no eixo etéreo e ouve o som das sete esferas celestes), a máquina do mundo passa pela 
Idade Média (veja-se a Divina comédia de Dante Alighieri e sua representação alegórica do mundo, "elemental" e "Celestial" ao mesmo tempo) e atinge grande apreço no Renascimento. Em consonância com o racionalismo mecanicista, o cientificismo e o humanismo da época, a contemplação alegórica do universo atinge então, segundo Fidelino de Figueiredo, "o requinte último da curiosidade geográfica e astronômica dos espíritos elevados, num tema sublime" (SANT’ANNA 1972: 245). Dir-se-ia, em termos simples, que a máquina do mundo contemplada é a representação poética, literária, das esferas armilares e das cartas de navegação que tanto prestígio tiveram - e tanto auxílio prestaram - na época das navegações e dos grandes descobrimentos. Conforme esse diapasão, o tema aparece em Frei Luís de Sousa e no Tratado da Sphera de Pedro Nunes (citados por Sant'Anna) e, em termos literários, no canto X, oitavas $76-80$, da epopéia Os Lusíadas (1572), de Camões.

Faço aqui duas observações importantes: a primeira diz respeito ao descompasso entre a concepção alegórica camoniana (francamente medieval, geocêntrica e teocêntrica, de raízes ptolomaico-aristotélicas) e a doutrina heliocêntrica, cuja primeira exposição sistemática data de 1543, com o De revolutionibus de Copérnico. Assim, se o poema camoniano é, por excelência, a epopéia da expansão marítima portuguesa (a parte "elemental" da máquina do mundo), não o é, todavia, a epopéia do propalado cientificismo e racionalismo característicos da época, no que concerne às novas teorias da origem e da dinâmica do universo (a parte "Celestial" da máquina do mundo): faltanos, até onde sei, um grande poema épico da Era Moderna onde o tema fosse pertinentemente explorado. Mas ao fim e ao cabo, essa ausência revela algumas características importantes da modernidade nascente (e de todo o processo de modernização que então se inicia): a substituir o mundo uno, fechado e coeso da Idade Média, está a fratura, a dissociação, a fragmentação, a relatividade. Tais características, diga-se de passagem, serão depois bastante exploradas por poetas líricos como Carlos Drummond de Andrade, cujo poema "A máquina do mundo" (em Claro enigma, 1951), ao recusar o maravilhoso representado pelo tema, o considera apenas como mais uma pedra no meio do caminho.

Essas últimas afirmações nos remetem à segunda observação que julgo importante: Camões, na verdade, estende a descrição da máquina do mundo até a estrofe 142 do canto X, praticamente até o epílogo da epopéia: as duas oitavas seguintes (143 e 144) são o fim da narração, pois tratam da volta do Gama e dos marinheiros ao lar depois de terem gozado na Ilha dos Amores tanto a "elemental" saciedade do corpo quanto a "Celestial" sapiência propiciada pela visão da máquina do mundo. As estrofes 145 a 156, como se sabe, marcam o epílogo do poema, sendo a primeira delas reveladora do desconcerto que assola a pátria natal do poeta. Ora, o tópico dodesconcerto (ou do mundo às avessas, com o qual se aparenta e se confunde), lembra Carlos Felipe Moisés, é em tudo contrário ao concerto, ao equilíbrio e à perfeição que caracterizam a máquina do mundo vista pelo Gama e os seus. Mais evidente na poesia lírica camoniana, nem por isso o desconcerto deixa de estar presente, de maneira sub-reptícia, n'Os Lusíadas, uma vez que é justamente a partir do Maneirismo que esse tópico ganha relevo. O livro de Moisés, $O$ desconcerto do mundo do Renascimento ao Surrealismo (2001), objetiva rastrear a maneira como esse desconcerto, então subjacente à visão clássica de mundo, maculando-a e rasurando-a, vai aflorar plenamente no século XX com a grande revolução surrealista. 
Moisés conclui que o concerto, para Camões - como para grande parte dos poetas modernos -, está apenas na máquina do poema, nessa consciência de linguagem que vinca o poeta português. O concerto, assim, "provém simplesmente da confiança que Camões deposita na própria poesia, na linguagem, na capacidade de expressão, enquanto tal. É esse o nível em que a aspiração à ordem e à harmonia se realiza" (MOISÉS 2001: 56).

O estudo das migrações de um topos como o da máquina do mundo - uma vez que as migrações, objeto da Literatura Comparada, são sempre plasmadas em temporalidades e espaços descontínuos -, revela, mais uma vez, que a máquina do poema continua a se alimentar de poesia, agora através da prática intertextual. Seja essa relação intertextual marcada pelageneralidade e pela codificação (no mundo clássico), seja exacerbando a particularidade e afragmentação (no mundo moderno), o certo é que essa prática é condição sine qua non da melhor literatura, pois ressalta, a um só tempo, o poeta enquanto leitor e enquanto autor de uma obra nova. Esta, ainda que evidentemente marcada pela peculiaridade de seu tempo e espaço, também se abre para o difícil diálogo com o passado. Isso revela não apenas a relação conflituosa do poeta com os precursores, mas também o modo como dado momento histórico-cultural recebeu a vasta herança desses precursores, problematizando-a sob variados ângulos. Moderna e contemporaneamente, a prática radical da intertextualidade crítica pode ser compreendida como a exploração (ainda que fragmentada e fragmentária, calcada e decalcada do palimpsesto da cultura) das "ruínas do passado" com as quais amparar as "ruínas do presente" (JUNQUEIRA 1987: 95).

\section{Três}

De um lado, a máquina do poema: consciência estética de que o poema é um objeto construído de linguagem e que tem seus mecanismos específicos de funcionamento, os quais, conjugados pelo talento e pela consciência do poeta, devem revelar por si mesmos a ordem, a harmonia, a coesão e o equilíbrio internos do poema. O conceito de máquina do poema é aspecto relevante de uma teoria, de uma poética e de uma prática lírica na modernidade e na contemporaneidade, e não pode apresentar as fissuras que a máquina do mundo sempre revela em si. Essa consciência estética - ou esse autotelismo estético - é a contrapartida do individualismo extremo do homem moderno, divorciado de seu meio e há muito afastado das experiências comuns do mito, do rito, do relato, da poesia. Por seu turno, como ressalta João Cabral de Melo Neto, o poeta também está divorciado de seu leitor, pois a poesia moderna, ao perder suas funções tradicionais e sua aura, voltou-se para si mesma e para os cacos da tradição e dos valores esfacelados, em busca de uma poética que exprimisse, por sua vez, as arruinadas concepções de Deus, mundo e vida. Mas a máquina do poema sinaliza também para o humano (mesmo sem Deus), sua capacidade simbólica e sua necessidade criativa, que se abrem sempre em novas possibilidades de fazer um mundo melhor que aquele configurado pela velha máquina do mundo, sempre em desconcerto. Refratando-se todos os prismas aqui veiculados, conclui-se que a máquina do poema é também uma concepção de mundo, uma cosmovisão, uma forma específica (subjetiva e objetiva) de conhecimento: seja da própria matéria poética; seja das relações da poesia (e da 
literatura em geral) com outros sistemas culturais e artísticos; seja das experiências de mundo e de vida plasmadas pelo eu-lírico.

De outro lado, a máquina do mundo: mera representação, cosmovisão ou concepção de mundo, mas poderosamente vincada pela realidade histórica e social de cada poeta que utilizou o tema. Em Dante Alighieri e Camões, por exemplo, é representação alegórica de um mundo poeticamente idealizado e ideologicamente mantenedor de valores como a Igreja, a Monarquia, o expansionismo, o absolutismo e outras certezas absolutas (ainda que sempre abaladas pela racionalidade em crise). Modernamente, recusa de toda maravilha e de qualquer solução mágica e mítica (como em Drummond), mais o vinco de ceticismo, amargor, desesperança e o cansaço de sempre ter de palmilhar as pedregosas estradas de Minas e do mundo às avessas. E é justamente esse tópico, disfarçado nas frinchas da concepção clássica, que vai, gradativamente, maculando tal concepção e expondo as fissuras da máquina do mundo universal. Esta, enfim - e coerentemente com o mundo arruinado em que vivemos - termina sobrepujada pelo tópico do mundo às avessasou do desconcerto do mundo: caro a Camões, esse tópico pode ser rastreado também em Drummond ("A flor e a náusea", entre outros), e é bastante familiar ao leitor contemporâneo. Mas, hoje em dia, não mais se representa a máquina do mundo? Como seria, hoje, uma representação dessa máquina? Veja-se o último delírio "cosmovisionário" (a expressão é de Leda Tenório da Motta) de Haroldo de Campos, A máquina do mundo repensada (2000): poema tripartite, de estofo épico (um épico da pós-modernidade esfacelada ou "pós-utópica", dir-se-ia), dialoga ao mesmo tempo com Dante, Camões e Drummond, está solidamente amparado pelas últimas conquistas científicas (astrofísicas) e é exemplar da consciência crítico-criativa do poeta e do aproveitamento que este faz das sobras da tradição poética. No poema de Haroldo, a máquina do mundo não deixa de ser pretexto para a máquina do poema.

Um outro exemplo, bastante complexo a meu ver, é o conjunto de sete novelas de João Guimarães Rosa, Corpo de baile (1956): além da mitopoesia, está presente na obra a cosmopoesia, uma vez que o autor mineiro, a partir do sistema planetário antigo (o mesmo explorado por Dante e Camões), configura, no sertão mineiro, através de um périplo elíptico - uma ciranda cósmica, um corpo de baile astral - um mundo bastante particular cuja construção revela na argamassa vários elementos da tradição clássica e medieval, quer em termos estéticos, quer em termos de pensamento filosófico, mítico, místico e metafísico. Ressalve-se, contudo, que esta interpretação genérica e generalizante de Corpo de baile deve sempre resguardar - e salientar - a máquina poemática que é cada novela do conjunto.

\section{OBRAS CITADAS}

\section{Geral}

BARBOSA, João Alexandre. 2002. Alguma crítica. São Paulo: Ateliê.

CAMPOS, Haroldo de. 2002. "De uma cosmopoesia: sobre A máquina do mundo repensada."Depoimentos de oficina. São Paulo: Unimarco. p. 59-70. JUNQUEIRA, Ivan. Intertextualismo e poesia contemporânea. O encantador de serpentes. Rio de Janeiro: Alhambra, 1987. p. 85-95. 
MELO NETO, João. 1998. Cabral. Prosa. Rio de Janeiro: Nova Fronteira. MOISÉS, Carlos Felipe. 2001. "A máquina do mundo." O desconcerto do mundo do Renascimento ao Surrealismo. São Paulo: Escrituras. p. 23-57.

MOTTA, Leda Tenório da. 2002. "Desastre de astros: Sobre o último Haroldo de Campos cosmovisionário." Sobre a crítica literária brasileira no último meio século. Rio de Janeiro: Imago. p. 163-187.

NUNES, Benedito. 1976. "A máquina do poema." O dorso do tigre. 2. ed. São Paulo: Perspectiva. p. 265-275.

SANT'ANNA, Affonso Romano de. 1972. "O enigma se esclarece." Drummond o gauche no tempo. Rio de Janeiro: Lia.

2. Obras literárias

ALIGHIERI, Dante. 2002. A divina comédia. Tradução e notas de Ítalo Eugenio Mauro. 3 vols. São Paulo: Editora 34.

ANDRADE, Carlos Drummond de. 1980. Antologia poética. 14. ed. Rio de Janeiro: J. Olympio.

—. 2002. Poesia completa. Rio de Janeiro: Nova Aguilar, 2002.

CAMÕES, Luís de. 1979. Os Lusíadas. São Paulo: Abril.

—. 1991. Lírica. Seleção, prefácio e notas de Massaud Moisés. São Paulo: Cultrix,.

CAMPOS, Haroldo de. 2000. A máquina do mundo repensada. São Paulo: Ateliê.

MELO NETO, João Cabral. 1997a. Serial e antes. Rio de Janeiro: Nova Fronteira.

—. 1997b. A educação pela pedra e depois. Rio de Janeiro: Nova Fronteira.

ROSA, João Guimarães. 1996. Manuelzão e Miguilim (Corpo de baile). 9. ed. Rio de Janeiro: Nova Fronteira.

—. 1978. No Urubuquaquá, no Pinhém (Corpo de baile). 6. ed. Rio de Janeiro: J.

Olympio.

—. 1979. Noites do sertão (Corpo de baile). 6. ed. Rio de Janeiro: J. Olympio. 


\title{
CONFISSÕES DE ANINHA E MEMÓRIA DOS BECOS
}

\author{
Solange Fiuza Cardoso Yokozawa (CAC - UFG)
}

RESUMO: Este trabalho propõe examinar aspectos da poesia memorialística de Cora Coralina e mostrar como esses aspectos conectam a poeta com a modernidade literária. A memória é um dos principais núcleos de criação da obra coralineana, seja a pessoal e artisticamente recriada, seja a "coletiva subterrânea", que a escritora resgata da clandestinidade para inscrevê-la nos autos do passado, reorganizando a história canônica. Ao tecer a sua poesia com os fios do tempo, distante dos centros culturais do país e dona de uma voz individualíssima, a autora encontra a tradição. PALAVRAS-CHAVE: autobiografia; memória coletiva; tradição literária.

Nas palavras dedicadas ao leitor que abrem Poemas dos Becos de Goiás e Estórias mais, primeiro livro publicado por Cora Coralina, diz a autora:

Alguém deve rever, escrever e assinar os autos do Passado antes que o Tempo passe tudo a raso.

É o que procuro fazer, para a geração nova, sempre atenta e enlevada nas estórias, lendas, tradições, sociologia e folclore de nossa terra. (CORALINA 1993: 39)

Ainda nas páginas introdutórias de Poemas dos Becos..., faz a seguinte ressalva:

$$
\begin{array}{r}
\text { Este livro foi escrito } \\
\text { por uma mulher } \\
\text { que no tarde da Vida } \\
\text { recria e poetiza sua própria } \\
\text { Vida. } \\
\text { (CORALINA 1993: 41) }
\end{array}
$$

Essas palavras, que funcionam como um prólogo ao livro, apontam para um dos traços principais da poesia coralineana: a recriação poética do tempo passado, a reinvenção lírica da memória. Essa memória lírica tem, como se pode depreender das citações e confirmar pela leitura da obra, tanto um caráter pessoal quanto coletivo. A escritora tanto transfigura em arte vivências individuais, notadamente a infância da menina mal amada Aninha, dando origem a poemas autobiográficos, às "meias confissões de Aninha", quanto recria histórias, lendas, resgata memórias subterrâneas que não constam nos autos oficiais do passado, de modo a promover um rearranjo da história canônica.

Essa bipartição da poesia mnemônica de Cora em pessoal e coletiva é feita apenas para efeito de sistematização desta leitura, vez que recordações individuais e lembranças coletivas estão intimamente ligadas. A memória grupal se inscreve nas linhas e entrelinhas da poesia confessional do mesmo modo que a leitura que a poeta faz do passado social é, como sói acontecer a toda manifestação artística autêntica, assinalada pela sua pessoalidade. Exemplar desse imbricamento é a moeda "vintém de cobre", que dá nome ao segundo livro da autora, Vintém de Cobre: Meias Confissões de Aninha, e nele aparece como motivo recorrente. Esse leitmotiv pode ser entendido, por um lado, 
como símbolo da infância pobre em economias e afeto de Coralina, quando ela era Aninha, a menina mal amada que vestia "mandrião de saias vermelhas" e "timão de restos de baeta", a menina que, sob a caçoada das colegas de escola, "guardava cinquinho e cinquinho / na esperança irrealizada / de inteirar quinhentos réis" (CORALINA 1993: 59). Por outro lado, o vintém pode ser tomado, numa cidade que se formou sob o ciclo do ouro, como símbolo da penúria a que Goiás se viu reduzida após o esgotamento aurífero no século XVIII; penúria que foi reforçada, na geração a que Coralina pertenceu, pela abolição da escravatura.

Vintém de Cobre: Meias Confissões de Aninha constitui a obra declaradamente autobiográfica da poeta, ainda que textos fundados em experiências particulares possam ser lidos em todas as suas publicações. Nesse livro, a autora demonstra ter consciência, através do adjetivo que antepõe a "confissões", das verdades partidas, dissimuladas, esparsas, que ela é capaz de confessar. Isso não só porque quem revela o vivido narra, além do que aconteceu, o que poderia ter acontecido, o que sonhou, imaginou, desejou, de modo a fazer do passado uma invenção do presente. Mas também porque, segundo a escritora, a conveniência, o preconceito, o medo dos vivos, dos mortos e de si mesma, as covardias retardadas e presentes, a tornam capaz de fazer apenas confissões pela metade, impossibilitando-a "de despedaçar a rede / onde se debate o escamado da verdade" (CORALINA 1995: 146).

Entre o que é possível revelar está o que precisa ser desvelado, o que parece causar um mal-estar na poeta porque ainda está mal dito, o que ela bem dirá através do discurso poético para convertê-lo em um bem-estar. Assim, em Vintém de Cobre..., Cora confessa, conforme se lê na apresentação do livro: "Alguma coisa, coisas que me entulhavam, me engasgavam / e precisavam sair" (CORALINA 1995: 43). . De fato, freqüentemente, nesse livro, a autora parece encontrar numa auto-análise, notadamente na análise psicológica da infância, a matéria nuclear de sua criação, dando origem a poemas altamente catárticos. Alguns textos de Poemas dos Becos..., como "Antigüidades", "Minha Infầncia" e "Vintém de Cobre", já apontam para a recuperação freudiana da infância perdida, mas nem sempre amada.

Esse resgate do passado constrói uma visão da infância diferente daquela edificada, sobretudo, pelos românticos e por muitos poetas do século XX, que reiteradamente tomam essa idade como um espaço privilegiado com o qual o artista pode manter uma correspondência feliz, em detrimento ao ingrato presente. Assim, enquanto para poetas como Casimiro de Abreu, Manuel Bandeira e Mario Quintana, a infância, ainda que inventada, é o paraíso perdido, o tempo para sempre amado, o espaço por excelência da saudade, para Cora Coralina, ela não constitui normalmente um reduto de felicidade, de amor e de saudade, de modo que a poeta, a exemplo de Graciliano Ramos em Infância, subverte o mito da meninice feliz e saudosa.

Não há uma intenção valorativa ao dizer que Cora subverte um imaginário recorrente de infância. A visão lírica e a concepção irônica de tempos pretéritos são formas diferentes, mas igualmente válidas, de reconstruções do passado. A eleição da puerícia como uma época de felicidade plena e, portanto, de saudade, parece ser corolário da fratura que se opera entre o artista e a modernidade. Não conseguindo se integrar na sociedade burguesa, não encontrando ressonâncias para sua arte na cidade modernizada, desacreditado do progresso técnico e científico, sofrendo as conseqüências dessas e de 
outras fraturas tais que, o artista busca, freqüentemente, em sua criação, recuperar um tempo em que ainda não houvesse se manifestado essa cisão entre o eu e o mundo. Floresce, assim, abundantemente, a recriação poética de um passado, notadamente a infância, em que é possível viver em estado de graça, com o qual é possível manter uma relação de fusão para resistir simbolicamente ao desencantamento do mundo. A recordação poética da meninice feliz seria, assim, uma das possibilidades de manifestação daquilo que Octavio Paz (1984) denomina "analogia". A analogia e a ironia, modos diferentes de negação da modernidade, constituiriam, segundo Paz, os dois princípios básicos a partir dos quais se estrutura a lírica moderna. A ironia representaria a manifestação deliberada da fissura entre o ser e o mundo moderno. A "analogia", a busca de um mundo em que não houvesse se manifestado essa fissura. No caso de muitos artistas modernos, a analogia recebe amiúde o nome de infância. Cora insere a fratura, a ironia, nesse espaço por excelência de correspondência, de amor e de saudade, como se pode ler no fragmento que se segue de "Menina mal amada":

Eu era uma pobre menina mal amada.

Frustrei as esperanças de minha mãe, desde o meu nascimento.

Ela espera e desejava um filho homem, vendo meu pai doente irreversível.

Em vez, nasceu aquela que se chamaria Aninha.

Duas criaturas idosas me deram seus carinhos:

Minha bisavó e minha tia Nhorita.

Minha Bisavó me acudia quando das chineladas cruéis da minha mãe.

No mais, eu devia ser, hoje reconheço, menina enjoada, enfadando as jovens da casa e elas se vingavam da minha presença aborrecida, me pirraçando, explorando meu atraso mental, me fazendo chorar e levar queixas doloridas para a mãe que perdida no seu mundo de leitura e negócios não dava atenção. Quem punia por Aninha era mesmo minha bisavó.

Me ensinava as coisas, corrigia paciente meus mal feitos de criança e exortava minhas irmãs a me aceitarem.

Daí minha fuga para o enorme quintal onde meus sentidos foram se aguçando para as pequenas ocorrências de que não participavam minhas irmãs.

(...)

Chamavam, mãe: vem ver Aninha...

Mãe vinha, ralhava forte.

Não queria que eu fosse para o quintal, passava a chave no portão.

Tinha medo, fosse um ramo de loucura, sendo eu filha de velho doente.

Era nesse tempo, amarela, de olhos empapuçados, lábios descorados.

Tinha boqueira, uma esfoliação entre os dedos das mãos, diziam: "Cieiro".

Minhas irmãs tinham medo que pegasse nelas.

Não me deixavam participar de seus brinquedos.

Aparecia na casa menina de fora, minha irmã mais velha passava o braço no ombro e segredava: "Não brinca com Aninha não. Ela tem Cieiro e pega na gente."

Eu ia atrás, batida, enxotada.

Infầncia... Daí meu repúdio invencível à palavra saudade, infância... 
Infầncia... Hoje, será.

(CORALINA 1995: 116-17)

A infância que nos pinta Cora, sem carinho de mãe e proteção de pai, regada a rejeição e desamor, apresenta cores muito diversas daquela evocada pela pena nostálgica de outros poetas. Vale sublinhar que a infância, na poeta goiana, não é objeto de saudade, mas de uma evocação freudiana. A saudade é uma modulação de amor. Como diz Eduardo Lourenço, ela é "a expressão do excesso de amor em relação a tudo o que merece ser amado" (1999: 13) . A infância daquela que diz ter sido "uma menina mal amada" não merece ser amada. Sua infância não pode ser, portanto, objeto de saudade. Daí o repúdio invencível da poeta às palavras saudade e infância.

Só o que merece ser amado entra no país da saudade, de modo que, em Coralina, são dignas desses sentimentos, sobretudo: Mãe Didi, a ex-escrava que a amamentou e the contava estórias de encantamento, a quem a poeta dedica um poema em Meu Livro de Cordel; a bisavó, uma das principais fontes memoriais e afetivas de sua poesia; e mestra Silvina, presença constante na poesia coralineana, a quem a autora dedica Vintém de Cobre... Silvina Ermelinda Xavier de Brito foi a única professora de Aninha, a menina que sentava no banco das mais atrasadas, aquela que, aprendendo a ler e a escrever através da dedicação da velha mestra, um dia se desencantaria em Cora Coralina.

É importante destacar que as confissões de Cora não são um mero derramamento pretensamente sincero de uma alma ingênua e incontida. Suas memórias pessoais são transfiguradas pela arte e qualquer produção digna desse nome é, em última instância, criação, ficção. Seria válido resgatar, nesse sentido, o sempre citado "Autopsicografia", de Fernando Pessoa, que está a nos lembrar que "o poeta é um fingidor / finge tão completamente / que chega a fingir que é dor / a dor que devera sente" (1990: 164) . Nesse poema, o verbo "fingir" não tem o caráter negativo que o senso comum lhe atribui. "Fingir", nesse caso, parece retomar o seu sentido etimológico de criação.Fingo/fingere (fingir), donde teria vindo a palavra latina fictionem, inicialmente tinha o significado de tocar com a mão, modelar na argila. $\mathrm{Na}$ Bíblia em latim, o verbo usado para dizer que Deus criou o homem é o verbo fingo/fingere. "Fingir", pois, nos versos pessoanos, pode significar criar, ficcionalizar. Ora, que o poeta seja um fingidor - no sentido de que não precisa haver uma consubstanciação entre viver e cantar, como pretendiam os românticos - é lugar comum nas teorias do texto poético. Mas Pessoa vai além e observa que o poeta, mesmo quando liriciza uma experiência vivida, como faz Cora em seus poemas autobiográficos, deve "fingi-la", ficcionalizá-la, de modo a transfigurá-la em arte, a fazê-la transcender as individualidades.

Exemplar desse fingimento em Coralina é a máscara que ela coloca, é o sujeito lírico que constrói, é a personagem que recria ao poetizar a sua infầncia: a menina Aninha. A poeta nasceu Ana Lins dos Guimarães Peixoto. Tão logo começou a publicar seus escritos em periódicos, adotou o pseudônimo com que o Brasil a conhece, o qual terminou por suplantar o seu nome de batismo e de registro. Mas ao revisitar poeticamente a infância, não fala em nome de Cora. Cora Coralina é a autora empírica que assina os versos. Nos poemas autobiográficos dedicados à infância, é Aninha a personagem, a persona, a máscara lírica da poeta. Em "Minha Cidade", essa máscara aparece pela primeira vez: "Eu sou aquela menina feia da ponte da Lapa / Eu sou 
Aninha" (CORALINA 1993: 47) . A equação simplista e freqüente do tipo Cora = Aninha pode ser enganosa. O eu poético declara ser Aninha da mesma forma que diz: "Eu sou aquele teu velho muro / verde de avencas", "Eu sou estas trepadeiras sem classe", "Eu sou a dureza desses morros" (CORALINA 1993: 47-48). Trata-se de um processo de composição metafórico recorrente na poesia coralineana. Há uma multiplicidade de "eus" nessa poesia e Aninha é um desses "eus". Um eu de raízes confessionais, é preciso reconhecer, mas que ultrapassa o mero biografismo, que ficcionaliza ou finge, como o quer Pessoa, a sua vivência, a sua dor particular, para convertê-la em experiência poética, em dor do mundo. Dessa conversão, a autora demonstra ter consciência quando, nas páginas iniciais de Vintém de Cobre..., diz estar certa de uma das conseqüências do livro: "muitas dirão: estas coisas também / se passaram comigo" (CORALINA 1993: 43).

A infância triste, cheia de privações da menina Aninha parece ter preparado em Cora Coralina, segundo Carlos Drummond de Andrade (1993: 22), uma percepção solidária das dores humanas. É assim que, ao recuperar literariamente as memórias coletivas do passado, ela privilegia aquelas vidas tão fadadas ao desamparo como foi a de Aninha: o menino lenheiro, "sem infância, sem idade"; a menina Jesuína, abraçada à sua boneca de pano e vítima de uma época em que criança não valia nada; a mulher da vida, "desprotegida e explorada / ignorada da Lei, da Justiça e do Direito"; a lavadeira do Rio Vermelho, "perdida no seu mundo / de trouxas e espuma de sabão"; enfim, a "gentinha" do beco, as vidas subterrâneas que não entraram na história canônica. Exemplar dessa preferência pelas "vidas obscuras" cujos nomes não foram assinados nos autos oficiais do passado é o poema que se segue:

\footnotetext{
"Todas as vidas"

Vive dentro de mim uma cabocla velha de mau-olhado, acocorada ao pé do borralho, olhando pra o fogo. Benze quebranto. Bota feitiço... Ogum. Orixá. Macumba, terreiro. Ogã, pai-de-santo...

Vive dentro de mim a lavadeira do Rio Vermelho. Seu cheiro gostoso d'água e sabão. Rodilha de pano. Trouxa de roupa, Pedra de anil sua coroa verde de são-caetano.

Vive dentro de mim a mulher cozinheira. Pimenta e cebola. Quitute bem feito.

Panela de barro.
} 


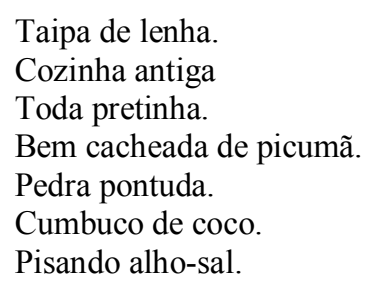

Vive dentro de mim a mulher do povo.

Bem proletária.

Bem linguaruda, desabusada, sem preconceito, de casca-grossa, de chinelinha, e filharada.

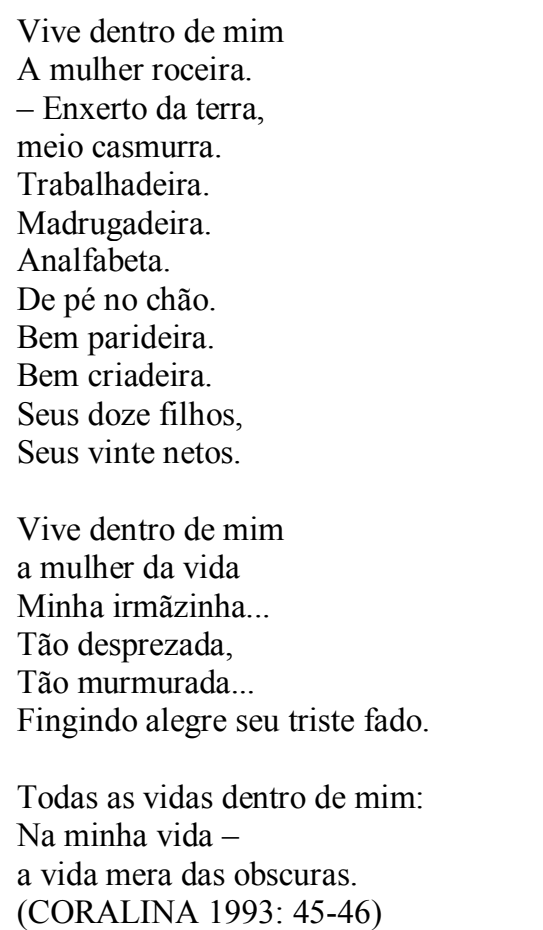

Entre todas as mulheres, gênero condenado por longo tempo ao limbo do esquecimento, a poeta se sensibiliza, sobretudo, com aquelas sobre as quais pesa um silêncio ainda maior, aquelas que, além de mulheres, constituem a escória da sociedade a que pertenceu Cora, a cabocla velha, a lavadeira, a cozinheira, a mulher do povo, a mulher roceira, a mulher da vida, de modo a conferir a essas "vidas obscuras" uma dignidade lírica, um caráter heróico.

Ao privilegiar um heroísmo poético que reabilita a periferia, a marginalidade, a clandestinidade, a poesia coralineana reorganiza a história oficial. Interessante nesse sentido é a opção da autora pela palavra estória para denominar a sua produção, seja a vazada em verso ou em prosa. Hoje nos parece imprópria a distinção entre história/estória. Isso porque já caiu no vulgo que a história, mesmo e sobretudo aquela escrita com $\mathrm{H}$, não passa de uma interpretação do passado, sendo, portanto, relativa, ficcional, e que a estória, assumidamente ficcional, muita vez, desvela o passado de uma 
maneira muito mais "verdadeira" que as histórias que se querem factuais. O próprio Aurélio recomenda apenas a grafia história, tanto no sentido de ciência histórica, quanto no de narrativa de ficção, conto popular, e demais acepções. Mas Cora escreve em uma época em que essa diferença ainda é sustentada e a poeta mantém a denominação de estórias para os autos do passado por ela recuperados literariamente. $\mathrm{O}$ termo aparece intitulando dois de seus livros:Poemas dos Becos de Goiás e Estórias mais e Estórias da Casa Velha da Ponte. Em Poemas dos Becos..., ela ressalva que o livro é "um modo diferente de contar velhas estórias". Aqui o modo diferente parece dizer respeito à forma literária, personalíssima, coralineana, com que as estórias de tempos idos são recontadas. No conto que dá nome ao livro O Tesouro da Casa Velha, a "velha rapsoda", a exemplo de Guimarães rosa, põe a "fábula em ata", ao resgatar, através da escrita literária, uma crônica do passado que ouvira de sua bisavó, uma de suas principais fontes mnemônicas: "minha bisavó contava. Não por ela mesma que isso é revelho, de ouvir contar a outra sua bisavó" (CORALINA 2000a: 43-44). Ao evidenciar que a sua fonte é a oralidade, fonte tão confiável (ou suspeita!) quanto outra, a escrita, privilegiada por muito tempo pela história, Cora problematiza a relação entre história e estória, fazendo a sua opção pela segunda:

História mesmo do acontecido, com $\mathrm{H}$, não encontrei em nenhum papel velho amarelado, mas que existiu, existiu mesmo. Minha bisavó, meu avô estavam cansados de contar, e os antigos eram sempre os donos da mentira e da verdade (...) Na falta do exato, forte e bem configurado, conto o que ouvi e a mais não estou empenhada, que história indagada, perquerida, é difícil na minha cidade (...) Nem eu tenho jeito de historiadora. (CORALINA 2000a: 44)

Negando-se a ser uma historiadora e assumindo-se como uma legítima contadora de estórias, a escritora termina por subverter a memória coletiva oficializada, por promover um rearranjo da história tradicional. Parafraseando Guimarães Rosa, pode-se dizer que, em Cora, a estória não quer ser história. A estória, nela, é contra a história. Contra uma história e uma memória coletiva uniformizadoras e opressoras, mas, é preciso que se lembre, irmanada com os modernos estudos de história e de memória. Nesse sentido, é oportuno lembrar um estudioso da área da memória, Michael Pollak. Assumindo posição contrária a Maurice Halbwachs, que acentua as funções positivas desempenhadas pela memória comum, notadamente a de reforçar a coesão social, Pollak acentua o caráter destruidor, uniformizador e opressor da memória coletiva. A esta se oporia a dos marginalizados, a das minorias, as memórias subterrâneas das culturas minoritárias e dominadas. Transmitidas de geração a geração oralmente e não através de publicações, essas memórias prosseguiriam seu trabalho de subversão no silêncio: "o longo silêncio sobre o passado, longe de conduzir ao esquecimento, é a resistência que uma sociedade civil impotente opõe ao excesso de discursos oficiais" (POLLAK 1989: 5). Ao aludir ao silêncio dos judeus sobreviventes ao Nazismo, observa Pollak: "Para poder relatar seus sofrimentos, uma pessoa precisa antes de mais nada encontrar uma escuta" (1989: 6) . Coralina parece ter sido a escuta mais eficiente das memórias subterrâneas dos becos de Goiás. Pertence ela àquela categoria de indivíduos que, ainda segundo Pollak, teimam "em venerar justamente aquilo que os enquadradores de uma memória coletiva em um nível mais global se esforçam por minimizar ou eliminar" (1989: 12). 
Ao reverenciar as memórias ocultas, a poeta não reorganiza apenas a história oficial, mas também o heroísmo da poesia épica e, ao fazê-lo, assume uma atitude poética que a conecta com a modernidade literária. Nesse sentido, Walter Benjamin (1989: 73), ao analisar a figura do herói em Baudelaire, diz que "para viver a modernidade, é preciso uma constituição heróica". Mas o herói épico não tem lugar numa sociedade moderna, de modo que é freqüentemente no lixo da sociedade (BENJAMIN 1989: 78) que o poeta francês o encontra. Cora Coralina, a exemplo de Baudelaire e da tradição moderna, também desentranhou o seu heró́smo do lixo humano, das "vidas obscuras" que a sociedade condenou à clandestinidade dos becos.

No caso do Brasil, essa tendência tornou-se prática consciente e coletiva a partir dos modernistas de 22, que, rejeitando a distinção entre temas poéticos e não poéticos, optaram pela poetização do que até então permanecera fora das esferas poéticas. E o que estava fora dessas esferas também estava, muita vez, fora das margens sociais. É assim que vamos encontrar personagens como o carregador de feira-livre João Gostoso, de "Poema tirado de uma notícia de jornal", de Manuel Bandeira, o moço leiteiro, de "Morte do leiteiro", de Carlos Drummond de Andrade, os indivíduos ínfimos celestados pela poesia de Manoel de Barros, as "vidas obscuras" iluminadas pela lírica de Cora Coralina, enfim, todos esses personagens que representam uma interpretação pessoal, um desdobramento da preferência modernista por poetizar os tipos humanos que até então permaneciam fora da poesia e da vida.

Vale insistir nessa relação da autora com a tradição poética moderna e modernista porque ela é freqüentemente lembrada pelo seu insulamento, pela sua independência em relação a qualquer estilo literário. Ela própria reforça esse mito ao dizer, quando indagada sobre a sua convivência com os poetas modernos brasileiros, que sempre viveu muito isolada literariamente, que lia muito pouco esses poetas porque na sua cidade não tinha livraria e quando viajava não dispunha de numerário para comprar livros (CORALINA 1990).

É verdade que a poeta escreveu o melhor de sua obra quando retornou à Cidade de Goiás, na década de 50, depois de ter passado quarenta e cinco anos no interior e na capital de São Paulo. Nessa época, Goiás, que recentemente havia deixado de ser capital do estado, não era uma cidade que favorecia a comunicação da doceira da casa velha da ponte com o resto do mundo. Mas viver em uma cidade cercada de morros por todos os lados e situada no interior do Brasil não impediu que Cora Coralina fosse lida por um poeta como Carlos Drummond de Andrade, que se encantou com a beleza dos seus versos e os revelou para o Brasil. Também não impossibilitou que ela travasse conhecimento com a literatura de seu país e do mundo, o que está assinalado explicitamente em sua poesia. Em um dos poemas sobre os becos de Goiás, conclama os poetas e pintores surrealistas, concretistas, cubistas a "cantar, rimar em versos, / bizarros coloridos, / os becos da minha terra" (CORALINA 1993: 119) . Em Vintém de Cobre..., parodia o Bandeira de "Vou-me embora pra Pasárgada" ao liricizar os "reinos da Cidade de Goiás, onde todos somos amigos do Rei" (CORALINA 1995: 43). Ainda nesse livro, faz alusão a Guimarães Rosa (CORALINA 1995: 168), escritor com quem compartilha o gosto pelo arcaísmo, o aproveitamento e a transformação da matéria regional. Em Meu livro de Cordel, há três poemas dedicados a Pablo Neruda, quando de sua morte. Em entrevista, a mesma escritora que afirma o seu isolamento literário 
reconhece o seu débito para com o estilo modernista: "Eu só me libertei da dificuldade poética depois do modernismo de 22 , mas não acompanhei o movimento - me achei dentro daquela mudança". A libertação aqui diz respeito ao verso livre. Cora Coralina começou escrevendo contos. Foi só depois da libertação formal da vanguarda de 22 que ela passou a escrever versos. Seus versos são exemplares da indistinção tão cara aos modernistas entre a forma da poesia e a da prosa; indistinção de que tem consciência a autora ao fazer a seguinte ressalva em Poemas dos Becos...: "Este livro: / Versos... Não / Poesia... Não. / um modo diferente de contar velhas estórias" (CORALINA 1993: 41).

Assim sendo, apesar de a crítica destacar o desprendimento da poeta de qualquer tradição literária, apesar de ela própria reiterar esse desprendimento, verifica-se que, nos momentos de maior individualidade e originalidade da sua obra, como é o caso de quando canta a "gentinha" do beco da sua cidade, ela fala em uníssono com a modernidade literária e o modernismo brasileiro, de modo a corroborar a tese de T. S. Eliot de que o poeta novo teria os passos melhores e mais significativos não naqueles aspectos de sua obra em que menos se parece com qualquer outro, como gosta de insistir certa tendência, mas naqueles onde "os poetas mortos, seus antepassados, mais vigorosamente afirmam a sua imortalidade" (s.d. 22).

Para finalizar estas considerações, vale lembrar que a memória, em Cora Coralina, é uma memória espacializada, fossilizada no espaço. Bachelard já chamou a atenção para a importância do espaço na preservação dos tesouros dos dias antigos. E o espaço que guarda, por excelência, o tempo recuperado em prosa e verso pela escritora é a Cidade de Goiás, ainda que encontremos textos como "Cântico de Andradina", "Cidade de Santos", "Ode a Londrina" e outros que privilegiam diferentes rincões do Brasil. É verdade que ao perscrutar a memória guardada pela sua cidade, ela apreende uma dimensão humana que desconhece fronteiras regionais, de modo a conferir uma força universal à sua poesia. Malgrado isso, é essencialmente a Cidade de Goiás o espaço memorial de onde desentranha a matéria de sua literatura.

Interessante é que Cora passou parte significativa de sua vida fora de Goiás Velha. Mesmo que ela escrevesse contos desde a adolescência, mesmo que nos tempos em que viveu no estado de São Paulo não tivesse abandonado a escrita, é quando, já viúva e tendo os filhos casados, volta para a sua cidade, para a casa velha da ponte, que ela escreve os versos que chamaram a atenção do país. Esses versos não estão fundados, essencialmente, no que a autora viveu nas terras paulistas. O contato com outros lugares parece ter-lhe amadurecido a inteligência, aguçado a sensibilidade lírica para rever e transfigurar em arte o passado que ela viveu ou ouviu contar e que está comprimido na Cidade de Goiás.

Nos "reinos da cidade de Goiás", dois são os espaços memoriais eleitos pela poeta, a casa velha da ponte e os becos. Para Bachelard, entre todos os espaços mnemônicos, a casa natal assume um papel de destaque, pois é ela que mantém a infância imóvel, é graças a ela que "um grande número de nossas lembranças estão guardadas" (1993: 27). Cora Coralina encontra na casa da ponte, que pertenceu ao seu avô, o espaço primeiro da memória pessoal, das poesias em que revisita freudianamente a infância. $\mathrm{O}$ visitante que vem a Goiás pode entrar nessa casa, percorrer seus aposentos, tomar água na biquinha e contemplar objetos que estão na poesia da autora, como é o caso do prato azul-pombinho, peça central de um belo poema lírico-narrativo. Mas a casa que aparece 
na literatura é mais que essa casa material em que o visitante pode penetrar, é mais que a casa que a poeta habitou na infância e a que regressou decorridos muitos anos de ausência. A casa natal, que guarda a infância, é mais que uma construção feita de taipa e telha, é uma casa-lembrança, que sempre habitou a escritora, mesmo em sua longa ausência, a ponto de ela dizer: "ter dado voltas ao mundo / sem deixar a sua casa" (CORALINA 1993: 193). Talvez mais que uma casa-lembrança, a morada paterna seja, como diz ainda Bachelard, uma "casa onírica", "uma cripta da casa natal", "uma casa lembrança-sonho, perdida na sombra de um além do passado verdadeiro" (BACHELARD 1993: 34). Uma casa lembrança-sonho reconstruída com palavras quando convertida em espaço de memória poética.

Da mesma forma que a casa materna guarda a infância, os becos conservam a memória das "vidas obscuras" resgatada pela poesia coralineana. Se o espaço é o responsável por comprimir o tempo, os becos, esses "vasos comunicantes onde / circulava a vida humilde da cidade" (CORALINA 1993: 117), compõem o reduto da memória grupal eleito por Cora. É esse espaço "estreito e sujo", "esquecido e abandonado" (CORALINA 1993: 119) e não os monumentos, que a poeta revisita através da reminiscência lírica. Beco é lugar onde as famílias vilaboenses jogavam o sem serventia. "Sapatos velhos. Velhas bacias. / Velhos potes, panelas, balaios, gamelas, / e outras furadas serventias" (CORALINA 1993: 109) compunham os monturos dos becos. Beco é lugar de galinha morta, "fedorenta. / Apodrecendo ao deus-dará" (CORALINA 1993: 107), de plantas que "nascem à toa", "sem amparo nem reparo de ninguém" (CORALINA 1993: 111). Nos becos, a sociedade jogava não só as coisas imprestáveis, mas também a escória, o lixo humano, a sujeira da sociedade. Beco é lugar "onde família de conceito não passava. / "Lugar de gentinha", "de gente do pote d'água. / De gente de pé no chão", de "mulher perdida" (CORALINA 1993: 104), de escravos "pulando o muro dos quintais, / correndo pra o jeguedê e o batuque" (CORALINA 1993: 108), de "vidas obscuras".

Em Poemas dos Becos..., a autora dedica três poemas a esse espaço marginal: "Becos de Goiás", "Do beco de Vila Rica", "Beco da escola". Mas mesmo quando recupera outros espaços, quando percorre outra geografia que não a vilaboense, pode-se dizer que a sua poesia é, metaforicamente, uma poética dos becos. É o que acontece, por exemplo, quando visita literariamente o Palácio Conde dos Arcos: "O Palácio dos Arcos / tem estórias de valor / que não quero aqui contar. / Vou contar a estória do soldado carajá" (CORALINA 1993: 129). No paço, a poeta encontra não os governadores de província que por lá passaram, mas o índio carajá, um soldado civilizado que, um dia, tendo seus atavismos despertados por um trovão, despiu a roupa e a civilidade e sumiu-se no rumo do Araguaia. É o que acontece também quando percorre outros sítios, donde desentranha heróis como Lampião (CORALINA 1995: 86), Tiradentes (CORALINA 1995: 131), os judeus errantes (CORALINA 1994: 41-42) e o obscuro Campos Sales (CORALINA 2000b: 17), não o ex-presidente, mas um negro sobrevivente da Guerra do Paraguai.

Cora Coralina, quando regressou à casa velha da ponte, depois de quarenta e cinco anos de ausência, encontrou nela guardada a infância; infância que revisita em versos que subvertem o mito da saudosa meninice feliz. O portão do quintal da casa que fossilizou o passado da poeta, a exemplo de tantas outras moradas de Goiás Velha, tem saída para 
o beco, o Beco da Vila Rica, lugar em que a "menina feia da ponte da Lapa", virada em Cora Coralina, perscrutou as memórias subterrâneas e as inscreveu poeticamente nos autos do passado, de modo a promover um rearranjo da memória coletiva oficializada e a conectar a memória poética dos becos com as avenidas da literatura moderna.

\section{OBRAS CITADAS}

ANDRADE, Carlos Drummond. 1993. "Cora Coralina, de Goiás.” Cora Coralina. 1993.

BACHELARD, Gaston. 1993. A poética do espaço. São Paulo: Martins Fontes. BENJAMIN, Walter. 1989. Charles Baudelaire um lírico no auge do capitalismo. São Paulo: Brasiliense.

CORALINA, Cora. 1990. Depoimento de Cora Coralina a Marlene Velasco. In:

VELLASCO, Marlene Gomes de. A poética da reminiscência; estudo sobre Cora Coralina. 1990. Diss. Mestrado em Letras e Linguística, Instituto de Ciências Humanas e Letras, Universidade Federal de Goiás, Goiânia.

—. 1993. Poemas dos becos de Goiás e estórias mais. 18.ed. São Paulo: Global, 1993.

- 1994. Meu livro de cordel. 5.ed. São Paulo.

—. 1995. Vintém de cobre: meias confissões de Aninha. 5.ed. São Paulo: Global.

—. 2000a. O tesouro da casa velha. 3.ed. São Paulo: Global.

—. 2000b. Estórias da casa velha da ponte. 9.ed. São Paulo: Global.

ELIOT, T. S. s.d. Ensaio de doutrina crítica. s.l.: Guimarães.

LOURENÇO, Eduardo. 1999. Mitologia da saudade. São Paulo: Cia das Letras.

PAZ, Octavio. 1984. Os filhos do barro: do romantismo à vanguarda. Rio de Janeiro:

Nova Fronteira.

PESSOA, Fernando. 1990. Obra poética. Rio de Janeiro: Nova Aguilar.

POLLAK, Michael. 1989. "Memórias, esquecimento, silêncio." Estudos Históricos (Rio de Janeiro) 2.3. 


\title{
MARLY DE OLIVEIRA E LYA LUFT: RECONSTRUINDO A SOLIDÃO INFANTIL
}

\author{
Angélica Soares (UFRJ)
}

RESUMO: Numa perspectiva feminista, focalizaremos poemas memorialísticos de Marly de Oliveira e Lya Luft, que recriam situações de medo e solidão experimentadas na infância. Partiremos do entendimento do dinamismo da memória, especialmente no que se refere ao tempo, ao sujeito recordador e à tensão entre as dimensões individual e social. O memorialismo poético será reconhecido como um modo de ficcionalização da tridimensionalidade temporal, de lembranças lacunares e do sujeito como mediador entre o passado e o presente, bem como ser projetado para o futuro. A indivisualização das lembranças constrói-se como uma metonímia, pois cada estória impõe-se como história do sistema educacional coercitivo, mais fortemente imposto à mulher pelo patriarcalismo e or uma concepção essencialista do gênero.

"O olho vê, a lembrança revê, e a imaginação transvê".

(Manuel de Barros 1997: 75)

O verso antológico, em epígrafe, desse grande poeta brasileiro bem introduz a relação entre memória e poesia, com a qual trabalharemos. $\mathrm{O}$ ato de transvisão, que integra $\mathrm{o}$ ver, o rever e o imaginar, por se configurar como uma conceituação poética da memória, nos parece a melhor forma de compreendermos como se projeta, nos versos, o que ficou para trás e se tornou irresgatável, em sua realidade palpável.

Por outro lado, nosso ponto de partida para o entendimento do dinamismo da memória e sua reconstrução literária são ainda as formulações de Bergson, para quem a memóriahábito, resultante da repetição, junta-se à memória-recordação, ligada à representação, às imagens-lembranças, que consistem na emergência afetiva de acontecimentos, evocada por sensações que retornam renovadas (BERGSON 1990: 57-70).

A recriação de situações que se projetam da "memória-hábito" e/ou das "imagenslembranças" integra a ficcionalidade do memorialismo poético, pois, da reelaboração do passado desrealizado resulta o verossímil. Assim, tem o poeta liberdade para refazer o acontecido.

Marilena Chauí, por sua vez, chama-nos a atenção para o seguinte: "o que foi não é uma coisa revista por nosso olhar, nem é uma idéia inspecionada por nosso espírito - é o alargamento das fronteiras do presente..." (1987: xviiii). Desse modo, nossas recordações adquirem sempre um sentido que ultrapassa ao da revivência. Refazemos o passado ampliando o presente, que se abre ao vir-a-ser, numa tridimensionalidade que habita cada experiência, pensamento ou sentimento já vivenciado. Desse modo, o passado é revisto a partir da perspectiva antecipante do futuro, unindo-se o começo ao fim. Lembremos que Mnemósine referencia, no radical "mne", a unidade, ligando "o que foi, o que é e o que será" (ver VERNANT 1970: cap. II). 
Acrescentemos a essas breves reflexões introdutórias o fato de que, embora haja, no ato de lembrar, um "eu" que seleciona e dá relevo a determinados acontecimentos, há sempre na lembrança uma tensão entre o individual e o social, uma vez que ela depende de seus relacionamentos com a família, a classe social, a escola, a profissão, tornando-se possível o resgate de elementos, de estratégias e do dinamismo do sistema social, porquanto se reconstrói um passado com imagens e idéias que guardam em si a memória coletiva da sociedade. A memória de um indivíduo está ligada à do grupo e esta à tradição. Daí que a estoricização das proibições na infância, em que se recriam traumas e situações de solidão como experiências individualizadas, testemunha a história de um processo de educação, que é exatamente o contrário do sentido originário do ex-ducere, do conduzir para adiante, do fazer emergir as potencialidades físicas, morais e intelectuais da criança, na direção de uma constante pulsão de vida, sob os desígnios libertários de Eros.

No memorialismo poético de Marly de Oliveira, esse estado de coisas assim se denuncia:

Foi desde sempre, de início, esse registro de ventos, cruéis e frios, que vedam todo alvoroço e alegria, se algo novo se concerta. Não foi minha ama uma fera, pois sei que de humano tinha uma beleza concreta: uns olhos que de tão verdes luziam na luz aberta que entrava pelas janelas, portas, varandas, jardins, da minha casa deserta.

De minha infầncia deserta, onde não cabia o sonho e a hera crescia muda; onda não havia trégua entre o meu medo e o desânimo. (Nenhuma pergunta ousada!) No entanto, que infiltração de suspeitas infundadas criando mel com as abelhas de que mal se imaginava. Pois desde cedo assentado ficara que, filho e gado, pastariam onde apenas lhe fosse imposto ou deixado. (OLIVEIRA 1989: 437)

A infância rememorada alarga, no presente, o sentido da opressão e o da desertificação, que presidiam (presidem ainda) uma lógica de censura patriarcal, que "veda" o sonho e o prazer, pondo, em seu lugar, "o medo e o desânimo" sem tréguas. Práticas opressivas presidem o processo de adestramento que, nessa lógica, se confundem com ensinar e aprender. Reduplicam-se, a cada geração, no âmbito da família e da escola, estratégias de desumanização do infante, numa relação mútua entre técnicas de saber e de poder. O 
livre exercício da criatividade, próprio da vida da criança, se vê impedido pela ação de "ventos cruéis e frios", dirigidos pela atuação da "ama", alicerçada na aproximação ideologicamente predominante entre "filho e gado".

Embora essas memórias nos tragam uma perspectiva individualizadora ("minha infância"), elas nos apontam, metonimicamente, para o ideal burguês de manutenção da ordem e, com ela, do poder, assegurada por métodos apropriados de sanções, de exclusões, de seleção..., que garantem a sua permanência, pelo impedimento de contestação de suas verdades, o que no texto se indica parenteticamente "(Nenhuma pergunta ousada)".

Esse procedimento, dito educacional, mas coercitivo e amedrontador, como sabemos através de documentos históricos recentes, atua mais fortemente quando voltado para a menina, por visar à garantia da passividade, da submissão e da fragilidade, que lhe são incutidas, como qualidades próprias de sua natureza feminina, pelo sistema falocêntrico e essencialista de sexo-gênero (MOI 1989: 122-24).

O medo vivenciado na infầncia é também fonte e motivo da poesia de Lya Luft, onde se acrescenta o sentimento da morte, prematuramente experimentado pela criança, em decorrência da solidão. Senão vejamos:

No relógio daquelas madrugadas, quando eu era menina e estava insone, a velhinha do Tempo tricotava longas tiras de medo: minha morte ia sendo preparada nessa trama. Sedas, farrapos, teias tão soturnas, todo o terror que eu esquecia quando me libertavam sol e cores. Alguma coisa ficou daquelas noites: o metal dos ponteiros, as agulhas, as mãos ossudas das bruxas noturnas, tudo continua na urdidura do fio singular da minha sorte. (LUFT 1984: 83)

Se anotarmos, mais uma vez, com Marilena Chauí, que o recordador "no que lembra e no como lembra, faz com que fique o que signifique" (1987: xxx), melhor poderemos avaliar quão significativo é trazer pela memória, da fase infantil para o presente, o mistério da morte. Ao invés do ingênuo e lúdico exercício vital, o que merece destaque, na infância, é o soturno e terrorífico "tricotar" da morte, pré-sentida no passado e conscientizada no presente da recordação. A leveza e o conforto do sono infantil, que seriam decorrentes da prática de uma liberdade sem medo, se vêem substituídos pela angústia, metaforizada nas "sedas", "farrapos" e "teias", com que a "velhinha do Tempo" produzia as "tiras de medo".

$$
* * *
$$

Inscrevendo-se como sujeito do discurso, denunciando o autoritarismo falocêntrico e pondo em questão a construção essencialista de identidades na transvisão memorialística, integradora do ver, do rever e do imaginar, a mulher escritora recria um 
olhar que, até quando inclui a instância do sonho, refaz o seu caráter políticodenunciatório.

Esses depoimentos literários da opressão na infância, por transporem através da dimensão social da memória, o universo de uma recordadora e por incluírem o futuro, posicionam a mulher frente ao todo de suas possibilidades.

Os movimentos feministas muito já avançaram, como sabemos, na modificação do status quo, atuando nas escolas, nas delegacias de mulheres, na medicina e, em especial, na psiquiatria e na psicanálise; mas muito ainda se tem a fazer para que as memórias das mulheres não estejam tão impregnadas da desertificação existencial e do terror, como as que selecionamos, entre tantas outras, para focalizar neste breve ensaio.

\section{OBRAS}

CITADAS:

BARROS, Manuel de. 1997. Livro sobre nada. Rio de Janeiro, Record. BERGSON, Henri. 1990. Matéria e memória. São Paulo, Martins Fontes. BOSI, Ecléa. 1987. Memória e sociedade; lembranças de velhos. 2. ed. São Paulo: T.A. Queiroz.

CHAUÍ, Marilena. 1987. "Os trabalhos da memória". Ecléa Bosi. Memória $e$ sociedade; lembranças de velhos. 2. ed. São Paulo: T.A. Queiroz. xvii-xxxii. DE LAURETIS, Teresa. 1999. "A tecnologia do gênero." Heloisa Buarque de Hollanda, org.Tendências e impasses; o feminismo como crítica da cultura. Rio de Janeiro, Rocco, 1999.

p. 228.

LUFT, Lya. 1984. Mulher no palco. Rio de Janeiro, Salamandra. MOI, Toril. 1989. "Feminist, Female, feminine. Toril Moi et alii. The feminist reader. London: Macmillan.

117-132.

OLIVEIRA, Marly de. 1989. Obra poética reunida. São Paulo: Massao Ohno. SOARES, Angélica. 1999. "Memória poética feminina: hierarquias em questão." Christina Ramalho, org. Literatura e feminismo; propostas teóricas e reflexões críticas. Rio de Janeiro: —. 1999. "Memória e poesia: interrogando a identidade em Lya Luft, Helena Parente Cunha, Hilda Hilst e Marly de Oliveira." Cadernos de Letras (Rio de Janeiro) 14: 106111.

VERNANT, Jean-Pierre. 1990. Mito e pensamento entre os gregos. 2 ed. Rio de Janeiro: Paz e Terra. 